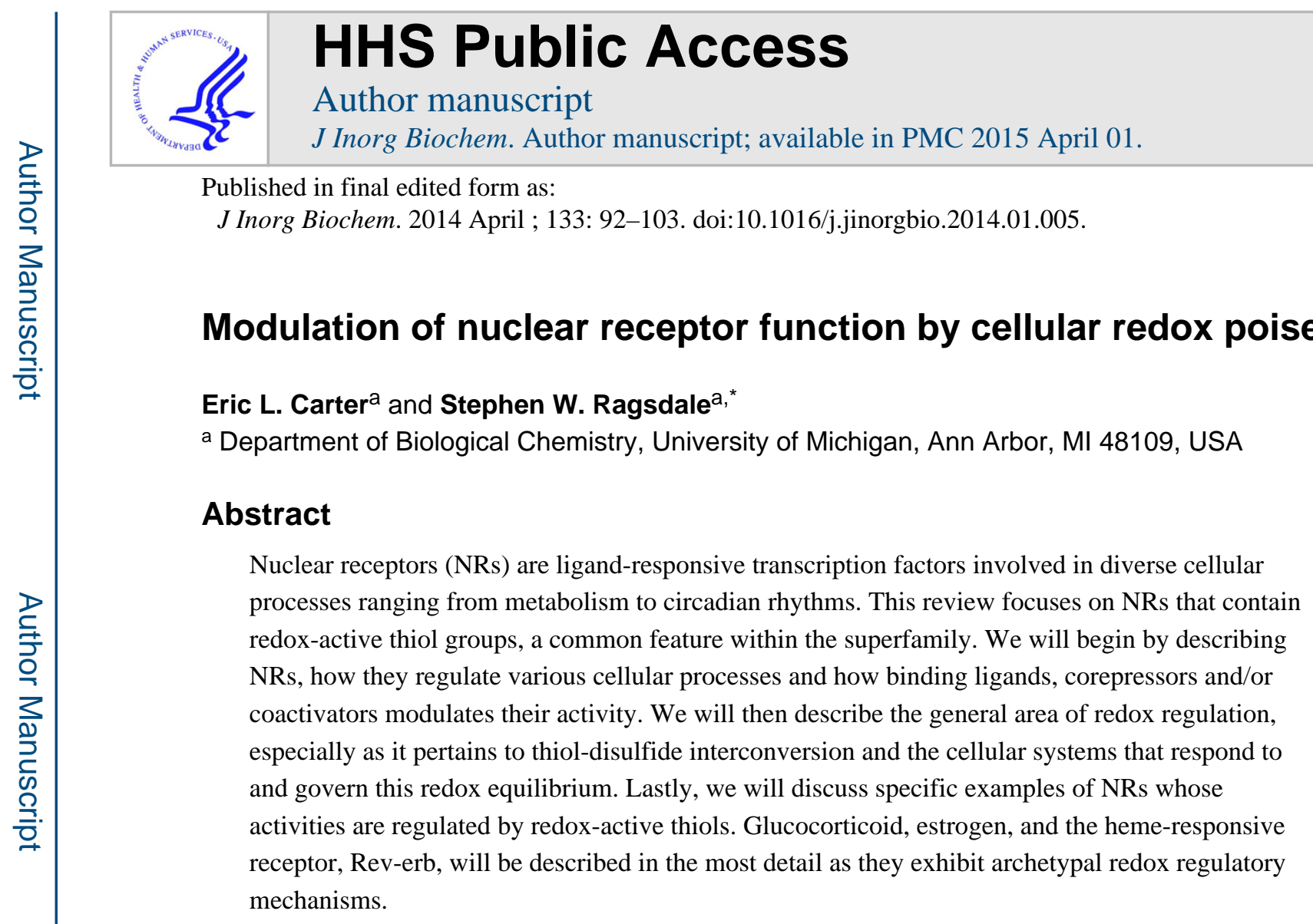

\title{
Keywords
}

redox; oxidative stress; nuclear receptor; transcription; hormone; thiol-disulfide

\section{Nuclear receptors}

Nuclear receptors (NRs) comprise a superfamily of eukaryotic ligand-responsive transcription factors that regulate genes involved in a vast array of cellular processes including metabolism, differentiation, reproduction, inflammation, and circadian rhythms. This class of proteins includes, among others, peroxisome proliferator-activated receptors (PPARs) that bind fatty acids, steroid receptors, and the heme-responsive receptor, Rev-erb. The human genome encodes $48 \mathrm{NRs}$, some of which remain orphaned as their endogenous ligands have yet to be identified. Of those NRs in which the ligand is known, several serve as pharmaceutical targets for the treatment of disease including estrogen receptors for an anti-breast cancer drug (tamoxifen), PPAR- $\gamma$ for thiazolidinediones used in the treatment of type II diabetes, and the glucocorticoid receptor for dexamethasone, used in the treatment of inflammation $[1,2]$.

(C) 2014 Elsevier Inc. All rights reserved

* Corresponding author at 1150 W. Medical Center Dr., 5220D MSRBIII, Department of Biological Chemistry, University of Michigan, Ann Arbor, MI 48109, USA. Tel.: +1 734615 4621; fax: +1 734763 4581. ericlc@ umich.edu (E.L. Carter) sragsdal@umich.edu (S.W. Ragsdale).

Publisher's Disclaimer: This is a PDF file of an unedited manuscript that has been accepted for publication. As a service to our customers we are providing this early version of the manuscript. The manuscript will undergo copyediting, typesetting, and review of the resulting proof before it is published in its final citable form. Please note that during the production process errors may be discovered which could affect the content, and all legal disclaimers that apply to the journal pertain. 
NRs are modular proteins that have a conserved architecture, consisting of a highly variable $\mathrm{N}$-terminal $\mathrm{A} / \mathrm{B}$ domain that is involved in ligand-independent transcriptional regulation (commonly referred to as activator function-1 (AF-1)) and is a site of phosphorylation (Figure 1, A). Adjacent to the A/B region is the highly conserved DNA-binding domain (DBD) or $\mathrm{C}$ region that harbors two $\mathrm{Cys}_{4}$ zinc-finger motifs. The DBD binds to specific DNA response elements in the promoter of target genes, participates in receptor dimerization, and can contain a nuclear localization signal (NLS). Linking the DBD to the C-terminal ligand-binding domain (LBD) is a poorly conserved hinge or D region that imparts flexibility to the receptor and in many cases contains a NLS. Near the C-terminus is the LBD (E region), which also contributes to receptor dimerization, can contain a NLS, and binds signaling molecules. In addition to the $\mathrm{LBD}$, some receptors also harbor a $\mathrm{F}$ region that does not appear to play a role in ligand-dependent transcriptional activation [3-5].

Ligand recognition by some NRs leads to dissociation from cytoplasmic heat shock protein complexes with subsequent nuclear localization. In the nucleus, the NR binds to its cognate DNA response element in the promoter of target genes and recruits transcriptional coactivators such as Steroid Receptor Coactivator (SRC-1, 2, and 3) that ultimately govern the level of target gene activation. Conversely, other NRs are predominantly nuclear and repress gene transcription in the ligand-free state by complexing with corepressors, e.g., Nuclear receptor CoRepressor (NCoR) and Silencing Mediator for Retinoid and Thyroid hormone receptors (SMRT); in this case, binding of ligand leads to dissociation of the corepressor in exchange for a coactivator [4-6]. With most NRs, ligand binding is accompanied by a major conformational change of LBD a-helix 12 (a.k.a activator function-2 helix, AF-2) from a position loosely associated with the rest of the globular domain to a compact structure in which it interacts with ligand and forms part of a hydrophobic cleft that serves as the binding interface for coactivators [7].

\section{An overview of cellular redox systems and thiol-disulfide redox regulation}

In addition to regulation by ligand and corepressor/coactivator binding, some NRs have been found to contain redox-sensitive thiol groups. Early studies of steroid hormone and vitamin D receptors demonstrated that thiol-attacking and modifying compounds like mercurials and iodoacetamide (IAA) adversely affected ligand and DNA binding ([8] and references therein). In many cases, reductants such as dithiothreitol (DTT) reactivated the NRs, implying that reduced sulfhydryls were required for ligand and/or DNA binding and that these activities could be regulated by the ambient cellular redox potential. It is now clear that redox poise has major functional ramifications on members of the NR superfamily and the pathways they control.

Various cellular redox systems can interface with NRs, allowing the NR to respond to redox poise and to control target pathways in response to perturbations to redox homeostasis. Cellular redox homeostasis is preserved as a delicate balance among three processes, (i) production of harmful reactive oxygen species (ROS) during metabolic and enzymatic processes, (ii) neutralization of ROS by the antioxidant defense system, and (iii) maintenance of equilibrium of the primary cellular redox couples such as 
glutathione:glutathione disulfide (GSH:GSSG), cysteine:cystine, NADPH:NADP ${ }^{+}$, and the reduced:oxidized thioredoxin system $[9,10]$ (Figure 2, A). ROS are generally characterized by those intermediates that arise during the successive reduction of dioxygen to water and include superoxide anion $\left(\mathrm{O}_{2} \bullet-\right)$, hydrogen peroxide $\left(\mathrm{H}_{2} \mathrm{O}_{2}\right)$, and hydroxyl radical $(\bullet \mathrm{OH})$. Endogenous ROS are produced at several distinct locations in the cell including mitochondria where complex I and III of the electron transport chain can spuriously reduce dioxygen to $\mathrm{O}_{2}{ }^{\bullet-}$ [11]. Additional ROS are generated as side reactions by cytochrome P450s [12], cyclooxygenase (COX) [13,14], lipoxygenase [14, 15], and uncoupled nitric oxide synthase (NOS) [16], and as physiological products of NADPH oxidases [17] and xanthine oxidase [18]. Free $\mathrm{H}_{2} \mathrm{O}_{2}$ is a substrate for Fenton chemistry in which free ferrous iron in the cell reacts with peroxide to form hydroxyl radical $\left({ }^{\circ} \mathrm{OH}\right)$, a potent oxidant that can damage DNA, lipids, and proteins non-specifically $[19,20]$. This reaction is potentiated via the reduction of labile ferric to ferrous iron by $\mathrm{O}_{2}{ }^{-}$completing the Haber-Weiss reaction. In addition to ROS, reactive nitrogen species are also present in the cell and include, among others nitric oxide ( $\mathrm{NO}^{*}$ ) produced by NOS isoforms, and the potent oxidant peroxynitrite, a combinatory product of $\mathrm{NO}^{\bullet}$ and $\mathrm{O}_{2}{ }^{-}$that readily oxidizes free thiols of glutathione and proteins [21] (Figure 2, B).

Under normal conditions, $\mathrm{O}_{2}{ }^{-}$is a short lived species that undergoes enzymatic dismutation to $\mathrm{H}_{2} \mathrm{O}_{2}$ and dioxygen in a reaction catalyzed by the metalloenzyme superoxide dismutase (SOD), which exhibits a high rate constant of $2 \times 10^{9} \mathrm{M}^{-1} \mathrm{~s}^{-1}$ [22]. Although most $\mathrm{H}_{2} \mathrm{O}_{2}$ generated by $\mathrm{O}_{2}{ }^{-}$dismutation or peroxisomal oxidases is reduced to water by antioxidant enzymes like catalases, peroxidases, and peroxiredoxins, steady-state concentrations in the nanomolar range can persist in tissues [20, 23, 24]. Both $\mathrm{H}_{2} \mathrm{O}_{2}$ and $\mathrm{O}_{2}{ }^{-}$can oxidize the major redox buffer glutathione leading to a more oxidizing cellular environment, although direct thiol oxidation by $\mathrm{H}_{2} \mathrm{O}_{2}$ is not likely to be a major reaction in the cell due its slow rate constant [25], rather the more rapid metal-catalyzed thiol oxidation by $\mathrm{H}_{2} \mathrm{O}_{2}$ is more likely [26]. In order to restore homeostatic GSH:GSSG levels, glutathione disulfide is reduced by glutathione reductase, an NADPH-dependent enzyme. ROS can also oxidize protein thiols to intra- or intermolecular disulfides, or to higher thiol oxidation states, including sulfinic, sulfenic, and sulfonic acids, modifications that typically augment activity (Figure 2, B). The ubiquitous thioredoxin (Trx) system consisting of NADPH-dependent Trx reductase and Trx, which contains a redox active pair of cysteine thiolates reduces disulfides of client proteins, thus, restoring activity [20]. Lastly, to circumvent the deleterious effects of free radicals including ${ }^{\circ} \mathrm{OH}$, the cell relies on a pool of low-molecular weight (LMW) antioxidants, including glutathione, tocopherols (vitamin E), and ascorbic acid (vitamin C) $[27,28]$. Thus, the cell has evolved distinct antioxidant mechanisms to counteract the inevitable generation of ROS and maintain redox homeostasis.

Perturbations to cellular redox homeostasis that increase ROS levels beyond the antioxidant threshold, or deplete the antioxidant pool can lead to oxidative stress. Numerous factors contribute to elevated ROS levels. For example, the natural progression of ageing is accompanied by increases in oxidative DNA and protein damage and oxidation of cellular redox buffers [10, 29, 30]. Exogenous contributors to heightened ROS levels are redoxactive drugs and environmental toxicants. A well-studied example is the chemotherapeutic agent doxorubicin, which contains a quinone functional group that accepts electrons from 
complex I of the respiratory chain and subsequently reduces dioxygen to $\mathrm{O}_{2}{ }^{\bullet-}[31,32]$. The resulting oxidative damage to NADH dehydrogenase in part accounts for the cardiotoxicity that accompanies treatment of cancer patients with doxorubicin. The widely used bipyridinebased herbicide, paraquat, redox cycles in the cell leading to the generation of ROS and depletion of the NADPH pool. Paraquat exposure has been linked to the development of Parkinson's disease implicating oxidative stress as a causal factor in this disorder [33, 34]. Physiologically relevant redox-active transition metals like iron, cobalt, and copper are catalysts of ROS production via Fenton chemistry; thus the cell has evolved complex molecular mechanisms to keep levels of free metals at a minimum. Other non-physiological metals and environmental toxicants like mercury and arsenic react with cellular thiols, depleting the levels of antioxidants, like glutathione [35].

Oxidative stress plays a role in the pathophysiology of many disorders including obesity [36] and diabetes [37], and is also implicated as a causal or perpetuating factor in neurodegenerative disorders including Parkinson's disease, Alzheimer's disease and amyotrophic lateral sclerosis [38]. Heightened oxidative stress is also observed in individuals experiencing disturbances in their circadian rhythm, for example, shift workers and people with sleep disorders [39, 40]. Indeed, the levels of some antioxidant enzymes (e.g., glutathione peroxidase) and low molecular weight antioxidants (e.g., melatonin) exhibit daily rhythms [41]. Thus, rhythm dysfunction caused by shift work may lead to imbalances in antioxidant pools and increases in ROS.

Redox homeostasis is a dynamic process in which host defense mechanisms adapt to manage the ebb and flow of ROS production, thus, the intracellular redox potential is also dynamic. For example, the ambient potential in proliferating cells is $\sim 60 \mathrm{mV}$ more reduced than in cells undergoing butyrate-induced differentiation [42] (Figure 2, A). $\mathrm{H}_{2} \mathrm{O}_{2}$-stressed yeast organelles exhibit a 50-100 $\mathrm{mV}$ oxidation of the GSH:GSSG couple, due in part to a decrease in cellular $\mathrm{pH}$ as a function of $\mathrm{H}_{2} \mathrm{O}_{2}$ [43]. According to the Nernst equation, a 60 $\mathrm{mV}$ oxidation equates to a $>50$-fold decrease in the GSH:GSSG ratio, which could have a profound effect on proteins with redox active thiols that are equilibrated with the GSH pool through an intermediate like glutaredoxin [44] . Indeed, there is a substantial amount of literature describing proteins that can "sense" ROS levels or the ambient redox potential through molecular switches comprised of one or more reactive cysteine thiols that undergo oxidative modification to disulfides, mixed disulfides with glutathione, higher sulfur oxides, or $S$-nitrosothiols leading to an alteration of function (Figure 2, B).

The activities of a variety of proteins, including enzymes, regulatory proteins and ion channels, are affected by the thiol/disulfide redox state. For instance, a thiol-disulfide redox switch exists in the C-terminal domain of heme oxygenase-2 (HO2), which catalyzes the degradation of heme to generate biliverdin, carbon monoxide (CO) and free iron. When the switch is in the dithiol form, the enzyme has a $\sim 10$-fold lower affinity for heme than in the oxidized disulfide state, implicating redox in the control of cellular concentrations of heme and $\mathrm{CO}$, both of which are signaling molecules [45]. In addition to HO2, a diverse set of transcriptional regulators from bacteria to mammals are modulated by redox poise, typically through thiol oxidation chemistry [20,46]. A well-studied example is OxyR, a LysR-type transcriptional regulator from bacteria that activates genes encoding antioxidant enzymes 
and proteins in response to $\mathrm{H}_{2} \mathrm{O}_{2}$ stress. Oxidation of a pair of conserved cysteines to the disulfide causes conformational changes that may enhance the ability of OxyR to interact with transcription machinery thereby triggering the OxyR regulon and curbing oxidative stress [47]. While OxyR is activated by disulfide formation, many transcriptional regulators lose the ability to bind DNA as a function of thiol oxidation. Especially relevant to this review is the class of proteins harboring zinc-finger motifs, which are typically composed of $\mathrm{Cys}_{2} \mathrm{His}_{2}$ - or $\mathrm{Cys}_{4}$-coordinated zinc atoms that impart structure needed to interact with DNA. Oxidation of zinc-finger thiolates to disulfides leads to structural destabilization, the release of $\mathrm{Zn}^{2+}$ and a loss of DNA binding ability (reviewed in [48, 49]). Indeed, several NRs are susceptible to zinc-finger oxidation via reaction with ROS, although this only represents one of several mechanisms by which NR activity is regulated at the level of thiol oxidation.

\section{NRs containing redox sensitive thiols}

In this section, we will assess the pertinent literature covering direct redox modulation of NRs and describe how changes in cellular redox poise affect the ability of NRs to regulate gene expression.

\subsection{Glucocorticoid receptor (GR)}

GR is a classic example of a ligand-regulated NR that undergoes nuclear localization upon binding a glucocorticoid hormone [50]. GR is expressed from the $\mathrm{NR} 3 \mathrm{Cl}$ gene with two major splicing variants resulting in GRa and GR $\beta$ isoforms. Since GR $\beta$ does not exhibit ligand-responsive activity and is generally considered a dominant negative isoform [51], GRa will be the focus of discussion and henceforth referred to simply as GR. GR transduces signal via binding of glucocorticoids, a class of steroid hormones characterized by their potent anti-inflammatory effects and regulation of critical cellular processes including glucose and lipid metabolism. The critical nature of the GR:glucocorticoid interaction is demonstrated in GR (-/-) mice, which perish shortly after birth due to respiratory failure [52].

The GR signaling pathway begins with ligand-free GR complexed with heat shock proteins (Hsp) in the cytoplasm, namely Hsp90, a molecular chaperone that derives energy from ATP hydrolysis in order to properly fold client proteins [53]. Hsp90 stabilizes the ligand binding conformation of GR. In the classic pathway, glucocorticoid binding causes GR to be released from the Hsp complex and undergo nuclear import via interaction of the nuclear translocation machinery with GR NLSs, one C-terminal to the second zinc-finger subdomain in the DBD and the other in the LBD [54]. Another Hsp90-dependent nuclear import pathway involves shuttling of the GR-Hsp complex to the nucleus by association with cytoskeletal motor proteins (reviewed in [55]). Once in the nucleus, GR homodimers bind cooperatively to DNA at glucocorticoid response elements (GREs), which consist of palindromic half-sites (the consensus sequence is 5'-AGAACAnnnTGTTCT-3') in the promoters of target genes. Coactivator complexes associate with the GR:GRE complex ultimately leading to an increase of gene transcription. 
In addition to the classic activation pathway, GR regulates transcription by a number of other strategies, including repression through binding to negative GREs, competition for promoter sites with other transcription factors, and coactivator squelching [56, 57]. Many of the anti-inflammatory effects that glucocorticoids exert through GR occur by transrepression, which is exemplified by the interaction of ligand-bound GR with NF- $\kappa \mathrm{B}$ or AP-1, transcriptional activator complexes that control genes encoding cytokines, chemokines, and proinflammatory enzymes like inducible nitric oxide synthase and COX-2. The resulting GR:NF- $\kappa \mathrm{B}$ or AP-1 complex results in a diminution of transcription of inflammatory genes, thus mitigating the inflammatory response [57].

The first reports suggesting thiol-disulfide redox modulation of GR were published over four decades ago. In these studies, which were performed in crude cell extracts or cytosolic preparations, thiol modification reagents including $N$-ethylmaleimide, $p$ chloromercuriphenyl sulfonic acid, mercury salts and IAA were shown to significantly decrease glucocorticoid binding [58-63]. However, pre-binding hormone to the receptor protected against binding inhibition as did the reductant, DTT [59, 61, 62]. Treatment with methyl methanethiosulfonate (MMTS), a thiol-reactive compound that results in a Cys-S-S$\mathrm{CH}_{3}$ adduct, led to a unique biphasic hormone response curve in which low concentrations of MMTS abrogated hormone binding; however, at high concentrations, hormone binding capacity rebounded but to only $\sim 70 \%$ of the control [64]. A model involving two proximal cysteine thiols at the opening of the steroid pocket was proposed in which, at low MMTS concentrations, one thiol reacts with MMTS to generate a mixed disulfide that is converted into an intramolecular disulfide by subsequent attack on the mixed disulfide by the other thiol; however, at high MMTS concentrations, both proximal thiols are modified preserving the opening to the steroid pocket. In addition, $\mathrm{H}_{2} \mathrm{O}_{2}$, diamide, and $\mathrm{NO}^{\circ}$ oxidize GR and inhibit steroid binding, presumably through the formation of the proximal cysteine disulfide or by $S$-nitrosylation, respectively. Thus, thiol modification could effectively act as a gatekeeper to the steroid binding pocket occluding access under oxidizing conditions (Figure $3, \mathrm{~A}, \mathrm{I})[65,66]$.

The proximal thiol-disulfide theory was validated by studies with the dithiol reactive compound arsenite ([67] and references therein) and the relevant Cys residues were identified by site-directed mutagenesis to be Cys656 and Cys661 (rat GR designation) [68]. This study also identified Cys640 as a participant in disulfide bond formation with the proximal thiols suggesting three reactive sulfhydryls involved in steroid binding. Further mutagenesis studies confirmed that mutations of these critical residues resulted in differential binding of glucocorticoids $[69,70]$. The crystal structure of the GR LBD demonstrated the proximity of the thiols to the hormone binding pocket (Figure 1, C) [71].

In addition to their negative effects on ligand binding, thiol modifying reagents including IAA, MMTS, 5,5'-dithiobis-(2-nitrobenzoic acid) and mercurials were shown to adversely impact GR DNA binding [62, 72-74]. Moreover, GR can only associate with a GRE under reducing conditions [75]. Treatment of GR by $\mathrm{H}_{2} \mathrm{O}_{2}$ leads to the formation of disulfides in the DBD and a loss of the ability to bind DNA-cellulose [74, 76], while $\mathrm{H}_{2} \mathrm{O}_{2}$ treatment stabilizes the Hsp90-GR complex likely through disulfide bond formation [74]. 
Despite ample in vitro data supporting redox-mediated ligand and DNA binding, one report in 1994 indicated that native GR in cell extracts did not contain disulfide bonds, calling into question the physiological relevance of the results described above [77]. Shortly thereafter, several in vivo studies demonstrated that GR activity was indeed altered by oxidative stress. Reduction of cellular GSH levels by treatment with diethylmaleate led to the inability of GR in extracts to bind a GRE, an effect that was reversed by feeding cells $\mathrm{N}$-acetylcysteine, which restores the GSH:GSSG balance [78, 79] . In addition, GSH deprivation led to the aberrant dexamethasone (DEX)-dependent activation of a GR reporter gene in cells [80]. Further in vivo studies demonstrated that $\mathrm{H}_{2} \mathrm{O}_{2}$ treatment decreased DEX-dependent transcriptional activation by GR due to inhibition of binding both DNA and hormone [81]. The potent thiol oxidizing agent, diamide also was shown to inhibit binding of recombinant GR DBD to the GRE.

Significantly, Trx led to the robust recovery of ligand and DNA binding activity of thiol oxidized GR in vivo and in vitro, confirming earlier reports that Trx stabilized GR activity in cytosolic preparations [81-83]. In addition, oxidative stress leads to the nuclear localization of Trx and its concomitant interaction with the DBD of GR. This finding gains more general impact considering that the DBD is the most conserved domain in the nuclear receptor superfamily and the conserved Cys residues in the zinc-finger domain may serve as a common mediator of redox signals [84]. ROS and Trx were shown to modulate GRmediated expression of the gene encoding the a-subunit of the amiloride-sensitive epithelial sodium channel, which is responsible for maintaining alveolar fluid balance [85]. When lung epithelial cells are subjected to $\mathrm{H}_{2} \mathrm{O}_{2}$-induced oxidative stress, GR cannot bind the GRE. However, overexpression of Trx restores the GR-GRE interaction. In another system, ineffective glucocorticoid treatment of alopecia aerate, or spot balding, has been linked to decreases in thioredoxin reductase levels in outer root sheath cells and a decline in GR:glucocorticoid reactivity, presumably mediated through loss of active Trx [86].

Oxidative stress also appears to inhibit hormone-dependent GR nuclear import (Figure 3, C) [87]. $\mathrm{H}_{2} \mathrm{O}_{2}$ treatment of human cells led to a concentration-dependent decline in the DEXinduced nuclear import of a green fluorescent protein-GR chimera (GFP-GR), while $\mathrm{N}$ acetylcysteine reversed the effect, indicating that thiol oxidation was culpable. Immunoprecipitation studies revealed that $\mathrm{H}_{2} \mathrm{O}_{2}$ caused the retention of GFP-GR in the cytoplasm as a complex with Hsp90. These results suggested that either DEX-binding was compromised or formation of the Hsp90:GFP-GR complex was stabilized by oxidation of thiols in the proximal disulfide gate. In order to test whether inhibition of nuclear import was strictly due to these redox processes, a chimeric protein was utilized that consists of GFP, the Herpes virus VP16 transactivation domain, and the GR DBD. This fusion construct contains the GR NLS1 and has been shown to be strictly nuclear and to promote transcriptional activation of a GRE-driven reporter construct [84]. Treatment of cells with $\mathrm{H}_{2} \mathrm{O}_{2}$ showed that the construct was partially retained in the cytoplasm. Substitution of a highly conserved cysteine residue in NLS1 (Cys481) to serine nullified the effect of $\mathrm{H}_{2} \mathrm{O}_{2}$ indicating that oxidation of this cysteine residue likely alters the conformation of GR such that it can no longer interact with the nuclear translocation machinery. Whether oxidation of Cys481 leads to formation of an intra- versus intermolecular disulfide, or a higher sulfur 
oxide is not clear, however this oxidative modification may influence other nuclear receptors considering the conservation of this cysteine residue in NLS1.

Redox regulation of GR may be a key mechanism of coupling oxidative stress to inflammation, but, if so, a fine balance between thiol oxidation and reduction must be maintained. Activation of glucocorticoid synthesis would help keep the effects of inflammation in check by downregulating the expression of pro-inflammatory systems. However, inflammatory cells produce ROS in order to destroy foreign invaders, thus, inflammation-derived ROS could in turn oxidize GR thiols consequently quelling glucocorticoid anti-inflammatory actions and potentiating the response. Furthermore, as mentioned above, GR interacts with NF- $\kappa \mathrm{B}$ in the nucleus and inhibits its ability to activate transcription of pro-inflammatory genes. However, ROS induce NF- $\kappa \mathrm{B}$ nuclear translocation while inhibiting the translocation of GR [46].

\subsection{Estrogen Receptor (ER)}

$17 \beta$-estradiol (estradiol) is a steroid hormone that controls growth and differentiation of cells originating from a variety of tissues such as bone, brain, and reproductive organs [88-90]. Estradiol signaling is transduced through binding to two subtypes of the estrogen receptor, ER $\alpha$ and ER $\beta$, which are transcribed from separate genes; in addition both $\alpha$ and $\beta$ subtypes have several splice variants. Although ERa and ER $\beta$ have some overlapping functions, they also have unique roles and differential tissue expression patterns [91]. Binding of estradiol to ER leads to receptor dimerization and subsequent binding to ER response elements (ERE) in the promoters of target genes. As with GR, ER can regulate gene transcription on multiple levels including binding of ER to the ERE followed by recruitment of coregulators, and interaction of ER with other transcription factors. ER can also associate with the cytoplasmic membrane and activate protein kinase cascades in an estradiol-dependent manner typifying non-genomic ER regulatory mechanisms [92].

In addition to its role in normal physiology, estradiol is implicated in the onset and progression of breast cancer through ER-dependent and -independent pathways [93]. For example, estradiol metabolism includes redox-active quinone intermediates that are associated with the formation of DNA lesions and the reduction of dioxygen to $\mathrm{O}_{2}{ }^{\bullet-}[94$, 95]. Moreover, ligand-bound ER is known to facilitate breast cell proliferation, which is thought to promote cancer as rapidly dividing cells are subject to accumulation of inevitable DNA mutations arising from mistakes during replication [96].

Although cysteine residues in the ER LBD have been shown to be important for coupling ligand binding to transcriptional regulation and cellular distribution [97-101], the LBD does not appear to be a candidate for redox sensing. For example, the dithiol reagent arsenite, which blocks glucocorticoid binding by GR, did not affect estradiol binding to ER or ligand binding to androgen receptor, mineralocorticoid receptor, or progesterone receptor [102].

As observed for GR, the ER DBD is redox regulated, containing two Cys 4 -zinc-fingers (ZF1 and ZF2) that are separated by a short 15-residue linker. A computational study indicated that, among 207 zinc-finger motifs, the thiols in ER ZF2 were the most reactive [103]. Significantly, the ER isolated from some breast cancer tissues lacks the ability to bind EREs 
and this effect is partially reversed by thiol reductants [104]. Furthermore, treatment of ER extracts and purified recombinant ER DBD with thiol oxidants (e.g., diamide, $\mathrm{H}_{2} \mathrm{O}_{2}$, iodosobenzoate, and IAA) inhibited binding of ER to its ERE and dithiothreitol reversed the inhibition. Circular dichroism experiments indicated a loss of alpha helical structure upon oxidation of the DBD implying significant structural alteration presumably due to the formation of intramolecular disulfides. Indeed, ER ligand binding was essentially unaffected in extracts treated with oxidants supporting the idea that the DBD was the primary target of oxidative damage. ER in living cells was also subject to oxidative damage induced by both $\mathrm{H}_{2} \mathrm{O}_{2}$ and menadione as demonstrated by a loss of DNA binding activity and the ability of ER to activate transcription of a reporter construct. Mass spectrometry studies revealed that $\mathrm{ZF} 2$ is the primary target of oxidative damage via disulfide formation and subsequent loss of $\mathrm{Zn}^{2+}$ (Figure 3, B) [105, 106]. Being more flexible than ZF1, the "open" structure of ZF2 could allow easier access of ROS to catalyze disulfide bond formation. The pronounced sensitivity of ZF2 to oxidation has been suggested as a means to target breast cancer through the use of electrophilic reagents, which disrupt ER activity and could inhibit proliferation of tumor cells [107].

$\mathrm{NO}^{\bullet}$ also interacts with the DBD, leading to $S$-nitrosylation and suppression of DNAbinding [108]. Similarly, NO inactivates DNA binding by androgen receptor and retinoid X receptor:vitamin D receptor heterodimer [109, 110]. Estradiol-binding by membraneassociated ER initiates a kinase cascade that stimulates nitric oxide synthase to produce $\mathrm{NO}^{*}$. In turn, $\mathrm{NO}^{*}$ may potentiate the non-genomic response by disabling the ability of ER to bind DNA. This pathway could in part explain the cardioprotective function of estrogens in terms of releasing $\mathrm{NO}^{*}$, a vasodilator, although many ER regulated genes are also thought to enhance vascular health, implicating both non-genomic and genomic ER functions in the maintenance of cardiovascular tissue [111]. $S$-nitrosylation of ER may also result from nitrosative stress, a condition characterized by non-physiological levels of reactive nitrogen species including $\mathrm{NO}^{\bullet}$ and peroxynitrite [21].

Shortly after their discovery that Trx regulates GR redox status, Tanaka and colleagues reported in vivo and in vitro experiments indicating that Trx is a crucial mediator of ER activity [112]. Transcriptional activation of a reporter construct is dose-dependently suppressed by $\mathrm{H}_{2} \mathrm{O}_{2}$ at a concentration $(20-50 \mu \mathrm{M}) \sim 5$-fold lower than that required to inhibit GR-dependent activation. Expression of Trx restores the activity of $\mathrm{H}_{2} \mathrm{O}_{2}$-damaged ER in live cells and enhances ER-driven expression in unstressed cells, indicating ER is partly oxidized even under normoxic conditions. In electromobility shift assays (EMSA) with recombinant ER, Trx reverses the suppression of DNA binding by diamide oxidation. Over a decade later, immunoprecipitation experiments demonstrated that Trx and ER interact in the nucleus [113]. This study also located TrxR in the Trx-ER nuclear complex and indicated that Trx and TrxR help maintain the structural integrity and activity of ER as well as affected estrogen-responsive gene expression and $\mathrm{H}_{2} \mathrm{O}_{2}$ levels. A splice variant, denoted TrxR1b [114], also appears to bind ER in the nucleus and to enhance ER-driven transcription at EREs, but to repress ER activation at AP-1 sites. Significantly, TrxR1b contains an LXXLL motif in an N-terminal extension that binds to ER; this sequence facilitates protein:protein interactions between coactivators and NR LBDs (Figure 1, C). 
Several studies have implicated a cadre of other redox mediators in the regulation of ER, including protein disulfide isomerase (PDI), superoxide dismutase (SOD) and redox effector factor-1 (Ref-1). In mass spectrometry studies, Nardulli and colleagues isolated ER within a large nucleoprotein complex containing PDI [115], which is known as an endoplasmic reticulum-associated molecular chaperone that catalyzes the formation and isomerization of disulfide bonds during protein folding [116]. Nonetheless, immunofluorescence and western blotting confirmed the presence of PDI in the nucleus. Chromatin immunoprecipitation (ChIP) experiments revealed that PDI localized at ERE elements in an estradiol-dependent manner and siRNA PDI knockdown indicated that PDI enhanced the transcription of some ER regulated genes, but repressed others. In vitro pulldown, limited proteolysis, and EMSA studies demonstrated that PDI directly interacts with ER, enhances ER binding to DNA and restores the activity of diamide-oxidized protein. Curiously, PDI mutants compromised in isomerase and chaperone activities retain the ability to enhance ER DNA binding.

Like PDI, SOD has been identified as a component of the nucleoprotein complex with ER and enhances binding of ER to DNA [117]. SOD knockdown diminished ER transcription and ChIP analysis revealed estradiol-dependent SOD localization at EREs. Furthermore, estradiol enhances SOD expression.

The other redox mediator identified in the ER:ERE complex was Ref-1, also known as apurinic/apyrimidinic endonuclease (APE) [118]. A critical component of the base excision repair machinery, Ref-1 has also been recognized as a redox mediator for several key transcription factors including AP-1, NF- $\kappa \mathrm{B}$, and p53 [119, 120]. In accord with TrxR/Trx, PDI, and SOD, Ref-1 was localized at EREs in an estradiol-dependent manner and was shown to enhance DNA binding by ER. Mutation of a critical redox-active Cys (C65S) in Ref-1 diminished the ability of ER to bind an ERE. Treatment of cells with specific inhibitors of either Ref-1 thiol-disulfide oxidoreductase or endonuclease activity indicated the former was required for modulating ER activity, and this was corroborated in vitro with a decline in Ref-1-enhanced ER DNA binding by treatment with the redox inhibitor. Similar to TrxR/Trx and PDI, Ref-1 knockdown by siRNA decreases expression of some ER target genes, but increases others, a counterintuitive effect considering that all of these proteins stimulate ER DNA binding in vitro. Nonetheless, Ref-1 is only one component of an apparent redox-mediator complex composed of Ref-1, PDI, TrxR/Trx, and SOD, thus knocking down a single component may have anomalous outcomes on gene expression. Another possibility raised in the case of the progesterone receptor (PR) expression (which was enhanced by Ref-1, PDI, and TrxR/Trx knockdown) was that additional transcriptional regulators like AP-1 that are modulated by Ref- 1 and target the PR gene may also be affected by Ref-1 knockdown. Adding to the complexity is the interplay between components of the redox-mediator complex (briefly reviewed in [118]), i.e. PDI is a chaperone of SOD and Trx, and Trx is known to reduce Ref-1, while both Trx and Ref-1 are known to stabilize the reduced forms of many transcription factors, as mentioned earlier.

In addition to direct redox modulation of ER activity, several reports indicate that other pathways affected by oxidative stress converge on ER. For example, induction of oxidative stress generally enhances ER $\beta$ expression with differential effects on ERa depending on the oxidant and the cell line used [121]. High glucose levels in culture medium induce oxidative 
stress analogous to hyperglycemia in diabetes mellitus and decrease ERa production while increasing $\mathrm{ER} \beta$ levels. Inclusion of a $\mathrm{O}_{2}{ }^{\bullet-}$ scavenger restored normal estradiol responses of ER isoforms under high glucose indicating heightened superoxide levels cause dysfunction of ER expression [122]. Lastly, phosphorylation of NRs is known to influence various functions from DNA and ligand binding to dimerization [123]. Furthermore, ROS have significant and differential effects on kinase signaling cascades, generally activating kinases and inactivating phosphatases through oxidation of a critical active-site thiol [20]. One study demonstrated that Induction of oxidative stress in cultured cells leads to an increase in phosphorylation of ERa Ser118 and Ser167, modifications implicated in the regulatory functions of ER [124, 125]. Overall, these studies suggest that redox regulation of ER is complex, occurring by direct and indirect mechanisms that ultimately have a profound impact on the transcription of ER target genes.

\subsection{Rev-erb}

Rev-erba and Rev-erb $\beta$ are isoforms unique to the NR superfamily in that they lack a-helix 12 responsible for recruitment of coactivators in other NRs. As a result, Rev-erba/ $\beta$ are constitutive transcriptional repressors. These NRs bind as monomers to a hexameric RORresponsive element (ROR-RE) comprised of the consensus sequence AGGTCA, or as dimers to the Rev-DR2 element consisting of direct ROR-RE repeats separated by two nucleotides [126-128]. Rev-DR2-bound Rev-erb homodimers recruit NCoR, a $\sim 270 \mathrm{kDa}$ protein that acts as a scaffold bringing together nuclear receptors with histone deacetylase complexes that repress gene expression by condensing chromatin and occluding access to the transcription machinery $[6,129,130]$. Rev-erbs compete for ROR-REs with RARrelated orphan receptors (RORs), with RORs acting as transcriptional activators [131].

Genes regulated by Rev-erb/ROR, notably BMAL1, apolipoprotein CIII (apoC-III), and plasminogen activator inhibitor type-1 (PAI-1), are involved in regulating diverse cellular functions, including the circadian clock, lipid metabolism and fibrinolysis, respectively. A master regulator of the human circadian rhythm, BMAL1 forms a heterodimeric complex with CLOCK to induce expression of Cryptochrome and Period, which heterodimerize to form a feedback loop by inhibiting the activity of BMAL1:CLOCK [132]. Correspondingly, Rev-erba knockout mice display increased expression of BMAL1 accompanied by alterations in circadian behavior [133]. Regulation of lipid metabolism by Rev-erb occurs by repressing expression of apoC-III, which controls serum triglyceride levels; thus, Rev-erba knockout mice have increased levels of triglycerides [134, 135]. In repressing the transcription of PAI-1, which is the principal inhibitor of fibrinolysis, Rev-erba plays an important role in myocardial infarction. Circulating levels of PAI-1 vary significantly according to the circadian clock, with its peak occurring in the morning, correlating to a greater chance for myocardial infarction during this time frame [136].

In addition to the preceding examples, Rev-erba also is a critical regulator of pro- and antiinflammatory cytokine [137, 138] and gluconeogenic genes [139]. Furthermore, knockout of both Rev-erb isoforms in mouse liver leads to compromised expression of circadian genes and pronounced dyslipidemia [140,141]. Taken together, these studies underscore the role 
of Rev-erbs in linking circadian rhythms with critical cellular processes such as inflammation and metabolic/lipid homeostasis.

Rev-erb remained orphaned until 2007 when two independent groups identified heme as its endogenous ligand $[139,142]$. This finding is suggested to explain how heme biosynthesis is controlled by the central clock, and how heme regulates the expression of clock genes [143]. In the first case, Rev-erba represses the transcription of PGC-1a, which is an inducer of the gene encoding the first and rate-limiting enzyme in tetrapyrrole biosynthesis, 5-

aminolevulinate synthase 1 [144]. A mechanism by which heme controls expression of clock genes is that binding of heme to the Rev-erb LBD promotes recruitment of NCoR and histone deacetylase 3, which leads to repression of Rev-erb target genes [139, 142]. Apparently, NCoR also associates with apo-Rev-erb, providing a basal level of repression that increases when Rev-erb binds heme [145].

Rev-erbs belong to a unique class of hemoproteins that undergo ligand switching in response to the reduction of $\mathrm{Fe}$ (III) ferric heme to Fe(II) ferrous heme. Based on spectroscopic [146, 147] and crystal structure [148] analyses, the LBD binds ferric heme as a 6-coordinate complex with His and Cys ligands and reduction to the ferrous heme results in a loss of thiolate ligation leading to a mixed 5-/6-coordinate system with neutral protein ligands presumed to be derived from His residues. Another possibility is that a protonated neutral thiol is bound to ferrous heme, as has been shown for other heme systems [149]. In E75 (the Rev-erb homolog in Drosophila), reduction of ferric to ferrous heme facilitated the interaction with a peptide derived from DHR3, a transcriptional activator that is repressed by heterodimerization with E75 [150]. Conversely, the redox state of heme in Rev-erb does not impact binding to a peptide derived from the nuclear receptor interaction domain of NCoR [142]. Thus, further studies are required to assess the contribution of heme redox state to regulation of gene expression.

The gaseous signaling molecules $\mathrm{CO}$ and $\mathrm{NO}^{\circ}$, known to play a role in controlling circadian rhythm timing [151], bind the ferrous heme in Rev-erb $\beta$ forming a 6-coordinate complex with the gas molecule opposite a His residue [146]. Pardee et al. demonstrated that NO, but not CO led to the derepression of Rev-erb target genes [148], however, because CO has such a high affinity for Rev-erb $\beta$ ferrous heme $\left(K_{d}=60 \mathrm{nM}\right)$ [147], the physiological relevance of $\mathrm{CO}$ binding should be closely examined. In E75, both $\mathrm{CO}$ and $\mathrm{NO}^{\bullet}$ destabilize the interaction with DHR3 [150]. In addition, NPAS2, a CLOCK homolog, binds heme and CO with the latter causing the dissociation of NPAS2:BMAL1 heterodimers [152]. The evidence described above suggests that $\mathrm{CO}$ and $\mathrm{NO}^{\circ}$ play roles in circadian rhythm maintenance; however the precise mechanism by which they control the molecular clock is not completely understood.

Another role for heme in the regulation of Rev-erb function is through differential binding to the Rev-erb $\beta$ LBD as a result of a thiol-disulfide switch between Cys384 and Cys374 in the heme-binding pocket [147]. Intriguingly, Cys384 is a heme axial ligand that is followed by a proline residue and along with other structural features, these Cys-Pro sequences are commonly referred to as heme regulatory motifs (HRMs) that modulate hemoprotein activity [153]. For example, the thiol-disulfide switch of HO is composed of two HRMs 
[45]. In the thiol-reduced state, Rev-erb $\beta$ binds ferric heme as a 6-coordinate His/Cys ligated complex that undergoes oxidation to form an intramolecular disulfide bond between Cys 384 and Cys374, which has a $\sim 5$-fold decreased affinity for heme relative to the reduced protein (Figure 3, A, II). Mutation of Cys374 to Ser abolishes the redox-dependent decrease in heme affinity, however the protein still undergoes a diamide-induced ligand switch suggesting that (i) Cys374-Cys384 form a molecular switch that controls the ability of Rev-erb $\beta$ to bind heme, recruit NCoR, and repress gene transcription as a function of cellular redox poise, (ii) the oxidation-induced ligand switch may be a separate regulatory mechanism, and (iii) since Cys374 is not conserved in Rev-erba, this may be an isoform-specific redox switch. The first hypothesis gains momentum when one considers a recent report that describes a daily rhythmic cycle of redox potential in suprachiasmatic nucleus (SCN) tissue, the brain structure responsible for maintaining circadian rhythms [154]. In that study, SCN tissue from a $B M A L 1(-/-)$ mouse was devoid of rhythmic redox fluctuations indicating the core molecular clock is involved in maintaining SCN redox poise. Reciprocally, the ability of the NPAS2/CLOCK:BMAL1 heterodimer to bind DNA is directly related to the ambient redox potential maintained by NADH:NAD ${ }^{+}$and NADPH:NADP ${ }^{+}$couples, with a more reducing environment favoring DNA binding [155]. Thus, redox poise seemingly controls circadian rhythms but is also dependent on a functional molecular clock. The Rev-erb $\beta$ thiol-disulfide switch may serve to integrate Rev-erb $\beta$ activity into the $S C N$ redox cycle, fine-tuning the repression of BMAL1, and likewise the ability of BMAL1:CLOCK heterodimers to bind DNA and activate clock-controlled genes (Figure 4). On the other hand, the Rev-erb $\beta$ Cys374-Cys384 disulfide may be a consequence of oxidative stress like the proximal thiols of GR. Therefore, it is crucial to determine the midpoint potential for the thiol-disulfide switch so as to discriminate between these mechanisms. In any case, it is clear that redox modulation of Rev-erb function has implications in the maintenance of circadian rhythm, the inflammatory response, and glucose/lipid homeostasis.

\subsection{Other redox-modulated NRs}

Androgen receptor (AR) - AR thiols have been implicated in both ligand and DNA binding $[156,157]$. Exposure of free AR to diamide diminishes its DNA binding capacity and stabilizes a homodimer of DNA-bound AR, suggesting that redox poise may play some role in the ability of AR to dimerize. Growth of prostate cancer cells under hypoxic conditions stimulates AR activity [158], suggesting that the low-oxygen tension may stabilize AR thiolates and decrease oxidation. Androgen deprivation therapy is a common treatment for aggressive prostate tumor growth, however its effectiveness may be thwarted in hypoxic cancer cells in which AR is responsive to low concentrations of androgens.

Mineralocorticoid receptor (MR) - A study in the late 1960's aimed at identifying aldosterone-binding protein complexes recognized the sensitivity of the receptor to sulfhydryl attacking reagents like $p$-hydroxymercuribenzoate [159]. Three decades later, several reports emerged confirming the critical role of reduced cysteine thiolates for ligand and DNA binding [160-163]. Oxidative stress induced in mice by depletion of GSH levels profoundly diminishes MR ligand binding capacity and activity that is thought to arise from two distinct mechanisms: (i) oxidative modification of thiols involved in ligand binding, and (ii) inhibition of cellular translation machinery [164, 165]. Conversely, a recent report 
suggests that oxidative stress induces MR activity through a Rac1-dependent mechanism [166]. Reactive nitrogen species have differential effects on MR activity with NO• suppressing MR-driven transcription likely by modification of DBD thiols, while peroxynitrite induces MR nuclear translocation and transcription of target genes [167].

Progesterone receptor (PR) - In the 1970s and 80s, a series of reports indicated that both ligand and DNA binding functions of PR were sensitive to oxidation and thiol attacking agents [168-174]. To our knowledge, direct redox modulation of PR has not been explored beyond these results.

Retinoic-acid receptor (RAR)-Similar to ER, the primary target of RAR redox modulation appears to be the DBD. Purified recombinant RAR-DBD loses DNA binding competence upon exposure to $\mathrm{H}_{2} \mathrm{O}_{2}$ or hypochlorite with concomitant loss of $\mathrm{Zn}^{2+}$. Oxidized protein can be regenerated by exposure to glutathione and $\mathrm{Zn}^{2+}$, likely due to reduction of intramolecular disulfides formed within zinc-finger motifs and re-insertion of the structural $\mathrm{Zn}^{2+}$ ion [175]. Functional consequences of RAR DBD oxidation was observed in melanoma cells in which transcription of a RAR-responsive reporter construct was influenced by the basal level of ROS produced in different cell lines with higher ROS leading to decreased RAR activity. Similar to AR, hypoxic conditions favored RAR transactivation [176]. Protection of RAR from oxidants and repair of oxidative damage in vivo is achieved by a hybrid redox-mediator protein thioredoxin glutathione reductase (TGR), which harbors thioredoxin and glutathione reductase domains and exhibits glutaredoxin activity [177]. TGR exhibits retinoic acid-dependent binding to RAR facilitated by a LXXLL motif found between the major reductase domains, reminiscent of the TrxRb1 variant described above. In addition, TGR appears to be required for efficient RAR-induced expression of a reporter construct in unstressed cells, and prevents the damaging effects of $\mathrm{H}_{2} \mathrm{O}_{2}$ treatment. Thus TGR joins PDI, Trx/TrxR, Ref- 1 and SOD as a bona fide NR redox mediator.

Thyroid hormone receptor (TR) - A recent report described the regulation of the growth hormone (GH) gene by TR as a function of Ref-1 and PDI [178]. The TR isoform TR $\beta 1$ was shown to enhance expression of the GH gene and was demonstrated via immunoprecipitation, to directly interact with Ref-1. On the other hand, PDI interacts with Ref- 1 and appears to catalyze the formation of a disulfide between the redox active Ref-1 thiolates. As a result, over-expression of PDI suppresses GH expression, presumably by inhibiting the Ref-1 redox modulation of TR. Trx overproduction had little effect on GH expression, although, because in these experiments cells had not been challenged with an oxidant, TR may have been fully reduced under normal growth conditions, in which case Trx would not be expected to have an effect. Nevertheless, this study underscores the importance of Ref- 1 and PDI in the regulation of NR target genes and suggests that such regulation is fine-tuned by the thiol-disulfide interplay between Ref-1 and PDI.

Vitamin D receptor (VDR)-Reduced VDR cysteine thiolates have been implicated in ligand [179] and DNA binding [8]. Furthermore, a site-directed mutagenesis study of conserved Cys residues in the VDR LBD implicated thiols as being important for high 
affinity ligand binding and VDR-driven transcriptional activation [180]. VDR heterodimerizes with the retinoid $\mathrm{X}$ receptor (RXR) to activate the transcription of target genes. The DNA binding function of VDR:RXR is sensitive to a cohort of cellular oxidants including $\mathrm{H}_{2} \mathrm{O}_{2}$, $\mathrm{NO}^{*}$, singlet oxygen, peroxyl radicals, and peroxynitrite, both in vitro and in vivo. Interestingly, cells are able to repair VDR:RXR that had been damaged via exposure to $\mathrm{NO}^{*}$, but not ROS indicating some level of irreversible modification of receptor thiols likely to higher sulfur oxides such as sulfonic acid [181].

\section{Conclusions}

Research focused on redox modulation of NR function spans over four decades with early in vitro studies identifying the requirement of reduced cysteine thiolates for efficient association of receptors with ligands. More recent work has established a clear link between cellular redox poise and NR activity, highlighting the role of oxidative stress in NR dysfunction.

There are three regions in the NRs that have been shown to be redox sensitive. Considering the high level of conservation and pronounced reactivity of DBD zinc-fingers, we propose that this domain is the main site of redox regulation within the NR superfamily and that the flexible ZF2 is the primary target of ROS/RNS-triggered disulfide formation. Similarly, the redox active conserved cysteine within NLS1 (e.g., Cys481 in human GRa/ $\beta$, Cys245 in ERa, and Cys209 in ER $\beta$ ) that modulates nuclear import of GR may also represent a common mode of NR redox modulation. The effect of redox poise on ligand binding appears to be receptor specific and largely depends on the occurrence of thiols near the ligandbinding pocket that can reversibly form disulfides as is the case for GR and Rev-erb $\beta$, but not ER. Since GR and Rev-erb $\beta$ govern pathways that are sensitive to redox poise, e.g. inflammation and circadian rhythm, modulating ligand binding through thiol-disulfide interconversion may serve to tune receptor function with changes in redox. All in all, the NR superfamily may be globally affected by redox poise especially through the highly conserved thiol-containing motifs with many NRs subject to redox regulation at multiple discrete points.

On a similar thread, the studies demonstrating redox modulation of ER, GR, RAR, and TR by Trx/TrxR, PDI, SOD, Ref-1, and TGR suggest a common mechanism in which thioldisulfide oxidoreductases, chaperones, and antioxidant enzymes protect and repair NRs from ROS-mediated thiol oxidation. It is important to establish whether these redox mediators bind independently and sequentially accomplish their function or exist as a pre-formed redox-chaperone complex in the nucleus. The latter scenario is attractive because it would allow such a complex to maintain the thiol-reduced and properly folded structure of critical transcriptional regulators including NRs. Linking the NR to such a complex could also represent a mechanism of fine-tuning in which redox poise is "sensed" by the complex and that signal is then transduced in the form of thiol oxidation or reduction of transcriptional regulators by PDI or Trx/Ref-1, respectively. In either case, it is clear that redox modulation of NRs is a highly coordinated mechanism involving thiol-disulfide conversion by ROS and oxidoreductases. Whether the oxidation event is strictly due to ROS interaction with NR thiols or perhaps catalyzed by PDI remains to be elucidated.

J Inorg Biochem. Author manuscript; available in PMC 2015 April 01. 
Although most redox regulation of NRs seems to be a function of oxidative stress, the thioldisulfide switches governing ligand binding (e.g., in Rev-erb $\beta$ ), DNA binding or nuclear localization for GR and perhaps other NRs may represent a redox sensor that integrates protein function and/or gene expression into the orchestrated cellular redox changes that occur as a function of the cell cycle and circadian rhythm. It is important to establish midpoint potentials of NR thiol-disulfide couples involved with redox signaling. For example, if a thiol:disulfide couple has a midpoint potential in the range of the GSH:GSSG couple under homeostatic growth conditions, i.e. between -260 and $-200 \mathrm{mV}$, it can act as a molecular switch that responds to changes in the ambient cellular redox poise (Figure 2, A). On the other hand, if the midpoint potential is significantly more positive than $-200 \mathrm{mV}$, the thiols would only be oxidized under apoptosis or oxidative stress conditions. To our knowledge, no quantitation of NR thiol-disulfide potentials exists in the literature, thus representing a void in our understanding of how NR function is modulated by changes in the ambient cellular redox potential.

Redox poise within the cell is a dynamic event that changes with the stage of cell growth, nutrient status and the circadian cycle. Redox homeostasis is also markedly altered during periods of oxidative stress, associated with events such as pathogen invasion or tissue damage. NRs are central to altering cellular metabolism during these various molecular, cellular, and systemic changes. We feel that studies should be launched to investigate the mechanism of redox regulation in various NRs. It also appears that chemicals that specifically target the redox active sites on NRs could form a novel class of pharmaceuticals.

\section{Acknowledgements}

This work was supported by the NIH NIEHS training grant for environmental toxicology and epidemiology (T32ES007062, University of Michigan) to ELC and a NIH NHLBI grant to SWR (R01HL 102662). We thank Angela Fleischhacker for a critical review of this manuscript.

\section{Table of abbreviations}

$\begin{array}{ll}\text { AF-1 } & \text { activator function-1 } \\ \text { APE } & \text { apurinic/apyrimidinic endonuclease } \\ \text { apoC-III } & \text { apolipoprotein CIII } \\ \text { AR } & \text { androgen receptor } \\ \text { ChIP } & \text { chromatin immunoprecipitation } \\ \text { CO } & \text { carbon monoxide } \\ \text { COX } & \text { cyclooxygenase } \\ \text { DBD } & \text { DNA-binding domain } \\ \text { DEX } & \text { dexamethasone } \\ \text { DTT } & \text { dithiothreitol } \\ \text { EMSA } & \text { electromobility shift assay }\end{array}$




\begin{tabular}{|c|c|}
\hline ER & estrogen receptor \\
\hline ERE & estrogen response element \\
\hline GFP & green fluorescent protein \\
\hline GH & growth hormone \\
\hline GR & glucocorticoid receptor \\
\hline GRE & glucocorticoid response element \\
\hline GSH & reduced glutathione \\
\hline GSSG & glutathione disulfide \\
\hline HO2 & heme oxygenase- 2 \\
\hline $\mathbf{H}_{2} \mathbf{O}_{2}$ & hydrogen peroxide \\
\hline Hsp & heat shock protein \\
\hline HRM & heme regulatory motif \\
\hline IAA & iodoacetamide \\
\hline LBD & ligand-binding domain \\
\hline MMTS & methyl methanethiosulfonate \\
\hline MR & mineralocorticoid receptor \\
\hline NADP $^{+}$ & oxidized nicotinamide adenine dinucleotide phosphate \\
\hline NADPH & reduced nicotinamide adenine dinucleotide phosphate \\
\hline NCoR & nuclear receptor corepressor \\
\hline NLS & nuclear localization signal \\
\hline NO & nitric oxide \\
\hline NR & nuclear receptor \\
\hline $\mathrm{O}_{2} \bullet-$ & superoxide anion \\
\hline$\cdot \mathrm{OH}$ & hydroxyl radical \\
\hline PAI-I & plasminogen activator inhibitor type I \\
\hline PDI & protein disulfide isomerase \\
\hline PPAR & peroxisome proliferator-activated receptor \\
\hline PR & progesterone receptor \\
\hline RAR & retinoic-acid receptor \\
\hline Ref-1 & redox effector factor- 1 \\
\hline RNS & reactive nitrogen species \\
\hline ROR & RAR-related orphan receptor \\
\hline
\end{tabular}

J Inorg Biochem. Author manuscript; available in PMC 2015 April 01. 


$\begin{array}{ll}\text { ROR-RE } & \text { ROR response element } \\ \text { ROS } & \text { reactive oxygen species } \\ \text { SCN } & \text { suprachiasmatic nucleus } \\ \text { SMRT } & \text { silencing mediator for retinoid and thyroid hormone receptors } \\ \text { SOD } & \text { superoxide dismutase } \\ \text { SRC } & \text { steroid receptor coactivator } \\ \text { TGR } & \text { thioredoxin glutathione reductase } \\ \text { TR } & \text { thyroid hormone receptor } \\ \text { Trx } & \text { thioredoxin } \\ \text { TrxR } & \text { thioredoxin reductase } \\ \text { VDR } & \text { vitamin D receptor }\end{array}$

\section{References}

1. Burris TP, Solt LA, Wang Y, Crumbley C, Banerjee S, Griffett K, Lundasen T, Hughes T, Kojetin DJ. Pharmacol. Rev. 2013; 65:710-778. [PubMed: 23457206]

2. Moore JT, Collins JL, Pearce KH. ChemMedChem. 2006; 1:504-523. [PubMed: 16892386]

3. Kumar V, Green S, Stack G, Berry M, Jin J-R, Chambon P. Cell. 1987; 51:941-951. [PubMed: 3690665]

4. Tsai M, O'Malley BW. Annu. Rev. Biochem. 1994; 63:451-486. [PubMed: 7979245]

5. Aranda A, Pascual A. Physiol. Rev. 2001; 81:1269-1304. [PubMed: 11427696]

6. Glass CK, Rosenfeld MG. Genes Dev. 2000; 14:121-141. [PubMed: 10652267]

7. Wurtz J-M, Bourguet W, Renaud J-P, Vivat V, Chambon P, Moras D, Gronemeyer H. Nat. Struct. Mol. Biol. 1996; 3:87-94.

8. Pike JW. Biochem. Biophys. Res. Commun. 1981; 100:1713-1719. [PubMed: 6271130]

9. Schafer FQ, Buettner GR. Free Radic. Biol. Med. 2001; 30:1191-1212. [PubMed: 11368918]

10. Dröge W. Physiol. Rev. 2002; 82:47-95. [PubMed: 11773609]

11. Turrens J. Biosci. Rep. 1997; 17:3-8. [PubMed: 9171915]

12. Bondy SC, Naderi S. Biochem. Pharmacol. 1994; 48:155-159. [PubMed: 8043018]

13. Im J-Y, Kim D, Paik S-G, Han P-L. Free Radic. Biol. Med. 2006; 41:960-972. [PubMed: 16934679]

14. Kukreja RC, Kontos HA, Hess ML, Ellis EF. Circ. Res. 1986; 59:612-619. [PubMed: 3028671]

15. Zuo L, Christofi FL, Wright VP, Bao S, Clanton TL. J. Appl. Physiol. 2004; 97:661-668. [PubMed: 15107407]

16. Thum T, Fraccarollo D, Schultheiss M, Froese S, Galuppo P, Widder JD, Tsikas D, Ertl G, Bauersachs J. Diabetes. 2007; 56:666-674. [PubMed: 17327434]

17. Paravicini TM, Touyz RM. Diabetes Care. 2008; 31:S170-S180. [PubMed: 18227481]

18. Kuppusamy P, Zweier JL. J. Biol. Chem. 1989; 264:9880-9884. [PubMed: 2542334]

19. Imlay JA, Chin SM, Linn S. Science. 1988; 240:640-642. [PubMed: 2834821]

20. Bindoli A, Rigobello MP. Antioxid. Redox Signal. 2013; 18:1557-1593. [PubMed: 23244515]

21. Dalle-Donne I, Scaloni A, Giustarini D, Cavarra E, Tell G, Lungarella G, Colombo R, Rossi R, Milzani A. Mass Spectrom. Rev. 2005; 24:55-99. [PubMed: 15389864]

22. Forman HJ, Fridovich I. Arch. Biochem. Biophys. 1973; 158:396-400. [PubMed: 4354035]

23. Chance B, Sies H, Boveris A. Physiol. Rev. 1979; 59:527-605. [PubMed: 37532]

J Inorg Biochem. Author manuscript; available in PMC 2015 April 01. 
24. Bonekamp NA, Völkl A, Fahimi HD, Schrader M. Biofactors. 2009; 35:346-355. [PubMed: 19459143]

25. Winterbourn CC, Metodiewa D. Free Radic. Biol. Med. 1999; 27:322-328. [PubMed: 10468205]

26. Pascal I, Tarbell DS. J. Am. Chem. Soc. 1957; 79:6015-6020.

27. Podda M, Grundmann-Kollmann M. Clin. Exp. Dermatol. 2001; 26:578-582. [PubMed: 11696061]

28. Pocernich CB, La Fontaine M, Butterfield DA. Neurochem. Int. 2000; 36:185-191. [PubMed: 10676851]

29. Ames BN, Shigenaga MK, Hagen TM. Proc. Natl. Acad. Sci. U. S. A. 1993; 90:7915-7922. [PubMed: 8367443]

30. Sohal RS, Weindruch R. Science. 1996; 273:59-63. [PubMed: 8658196]

31. Cadenas E, Davies KJA. Free Radic. Biol. Med. 2000; 29:222-230. [PubMed: 11035250]

32. Marcillat O, Zhang Y, Davies K. Biochem. J. 1989; 259:181-189. [PubMed: 2719642]

33. Cocheme HM, Murphy MP. J. Biol. Chem. 2008; 283:1786-1798. [PubMed: 18039652]

34. Bus JS, Gibson JE. Environ. Health Perspect. 1984; 55:37-46. [PubMed: 6329674]

35. Valko M, Morris H, Cronin MTD. Curr. Med. Chem. 2005; 12:1161-1208. [PubMed: 15892631]

36. Furukawa S, Fujita T, Shimabukuro M, Iwaki M, Yamada Y, Nakajima Y, Nakayama O, Makishima M, Matsuda M, Shimomura I. J. Clin. Invest. 2004; 114:1752-1761. [PubMed: 15599400]

37. Sonta T, Inoguchi T, Tsubouchi H, Sekiguchi N, Kobayashi K, Matsumoto S, Utsumi H, Nawata H. Free Radic. Biol. Med. 2004; 37:115-123. [PubMed: 15183199]

38. Barnham KJ, Masters CL, Bush AI. Nat. Rev. Drug Discov. 2004; 3:205-214. [PubMed: 15031734]

39. Sharifian A, Farahani S, Pasalar P, Gharavi M, Aminian O. J. Circadian Rhythms. 2005; 3

40. Esquirol Y, Bongard V, Mabile L, Jonnier B, Soulat J-M, Perret B. Chronobiol. Int. 2009; 26:544559. [PubMed: 19360495]

41. Hardeland R, Coto-Montes A, Poeggeler B. Chronobiol. Int. 2003; 20:921-962. [PubMed: 14680136]

42. Kirlin WG, Cai J, Thompson SA, Diaz D, Kavanagh TJ, Jones DP. Free Radic. Biol. Med. 1999; 27:1208-1218. [PubMed: 10641713]

43. Ayer A, Sanwald J, Pillay BA, Meyer AJ, Perrone GG, Dawes IW. PLoS ONE. 2013; 8:e65240. [PubMed: 23762325]

44. Jones, DP. Methods Enzymol. Helmut, S.; Lester, P., editors. Vol. 348. Academic Press; 2002. p. 93-112.

45. Yi L, Ragsdale SW. J. Biol. Chem. 2007; 282:21056-21067. [PubMed: 17540772]

46. Brigelius-Flohé R, Flohé L. Antioxid. Redox Signal. 2011; 15:2335-2381. [PubMed: 21194351]

47. Choi H-J, Kim S-J, Mukhopadhyay P, Cho S, Woo J-R, Storz G, Ryu S-E. Cell. 2001; 105:103113. [PubMed: 11301006]

48. Webster KA, Prentice H, Bishopric NH. Antioxid. Redox Signal. 2001; 3:535-548. [PubMed: 11554443]

49. Wilcox DE, Schenk AD, Feldman BM, Xu Y. Antioxid. Redox Signal. 2001; 3:549-564. [PubMed: 11554444]

50. Picard D, Yamamoto KR. EMBO J. 1987; 6:3333-3340. [PubMed: 3123217]

51. Yudt MR, Cidlowski JA. Mol. Endocrinol. 2002; 16:1719-1726. [PubMed: 12145329]

52. Cole TJ, Blendy JA, Monaghan AP, Krieglstein K, Schmid W, Aguzzi A, Fantuzzi G, Hummler E, Unsicker K, Schütz G. Genes Dev. 1995; 9:1608-1621. [PubMed: 7628695]

53. Prodromou C, Panaretou B, Chohan S, Siligardi G, O'Brien R, Ladbury JE, Roe SM, Piper PW, Pearl LH. EMBO J. 2000; 19:4383-4392. [PubMed: 10944121]

54. Freedman ND, Yamamoto KR. Mol. Biol. Cell. 2004; 15:2276-2286. [PubMed: 15004228]

55. Echeverria PC, Picard D. Biochim. Biophys. Acta. 2010; 1803:641-649. [PubMed: 20006655]

56. Dostert A, Heinzel T. Curr. Pharm. Des. 2004; 10:2807-2816. [PubMed: 15379669]

J Inorg Biochem. Author manuscript; available in PMC 2015 April 01. 
57. De Bosscher K, Vanden Berghe W, Haegeman G. Endocr. Rev. 2003; 24:488-522. [PubMed: 12920152]

58. Koblinsky M, Beato M, Kalimi M, Feigelson P. J. Biol. Chem. 1972; 247:7897-7904. [PubMed: 4640929]

59. Rees AM, Bell PA. Biochim. Biophys. Acta. 1975; 411:121-132. [PubMed: 170996]

60. Baxter JD, Gordon MT. Proc. Natl. Acad. Sci. U. S. A. 1971; 68:932-937. [PubMed: 4396919]

61. Harrison RW, Woodward C, Thompson E. Biochim. Biophys. Acta. 1983; 759:1-6. [PubMed: 6309245]

62. Young HA, Parks WP, Scolnick EM. Proc. Natl. Acad. Sci. U. S. A. 1975; 72:3060-3064. [PubMed: 171651]

63. Schaumburg BP. Biochim. Biophys. Acta. 1972; 261:219-235. [PubMed: 5012467]

64. Miller NR, Simons SS. J. Biol. Chem. 1988; 263:15217-15225. [PubMed: 3170579]

65. Bresnick EH, Sanchez ER, Harrison RW, Pratt WB. Biochemistry. 1988; 27:2866-2872. [PubMed: 3401453]

66. Galigniana MD, Piwien-Pilipuk G, Assreuy J. Mol. Pharmacol. 1999; 55:317-323. [PubMed: 9927624]

67. Stancato LF, Hutchison KA, Chakraborti PK, Simons SS, Pratt WB. Biochemistry. 1993; 32:3729_ 3736. [PubMed: 8466913]

68. Chakraborti PK, Garabedian MJ, Yamamoto KR, Simons SS. J. Biol. Chem. 1992; 267:1136611373. [PubMed: 1597467]

69. Chakraborti PK, Garabedian MJ, Yamamoto KR, Simons SS. J. Biol. Chem. 1991; 266:2207522078. [PubMed: 1939229]

70. Yu C, Warriar N, Govindan MV. Biochemistry. 1995; 34:14163-14173. [PubMed: 7578014]

71. Bledsoe RK, Montana VG, Stanley TB, Delves CJ, Apolito CJ, McKee DD, Consler TG, Parks DJ, Stewart EL, Willson TM, Lambert MH, Moore JT, Pearce KH, Xu HE. Cell. 2002; 110:93-105. [PubMed: 12151000]

72. Bodwell JE, Holbrook NJ, Munck A. Biochemistry. 1984; 23:1392-1398. [PubMed: 6722099]

73. Rousseau GG, Higgins SJ, Baxter JD, Gelfand D, Tomkins GM. J. Biol. Chem. 1975; 250:60156021. [PubMed: 168206]

74. Tienrungroj W, Meshinchi S, Sanchez ER, Pratt SE, Grippo JF, Holmgren A, Pratt WB. J. Biol. Chem. 1987; 262:6992-7000. [PubMed: 3584105]

75. Silva CM, Cidlowski JA. J. Biol. Chem. 1989; 264:6638-6647. [PubMed: 2708329]

76. Hutchison KA, Matić G, Meshinchi S, Bresnick EH, Pratt WB. J. Biol. Chem. 1991; 266:1050510509. [PubMed: 1709934]

77. Opoku J, Simons SS. J. Biol. Chem. 1994; 269:503-510. [PubMed: 8276843]

78. De Rosa SC, Zaretsky MD, Dubs JG, Roederer M, Anderson M, Green A, Mitra D, Watanabe N, Nakamura H, Tjioe I, Deresinski SC, Moore WA, Ela SW, Parks D, Herzenberg LA. Eur. J. Clin. Invest. 2000; 30:915-929. [PubMed: 11029607]

79. Whillier S, Raftos JE, Chapman B, Kuchel PW. Redox Report. 2009; 14:115-124. [PubMed: 19490753]

80. Esposito F, Cuccovillo F, Morra F, Russo T, Cimino F. Biochim. Biophys. Acta. 1995; 1260:308314. [PubMed: 7873605]

81. Makino Y, Okamoto K, Yoshikawa N, Aoshima M, Hirota K, Yodoi J, Umesono K, Makino I, Tanaka H. J. Clin. Invest. 1996; 98:2469-2477. [PubMed: 8958209]

82. Grippo JF, Tienrungroj W, Dahmer MK, Housley PR, Pratt WB. J. Biol. Chem. 1983; 258:1365813664. [PubMed: 6643445]

83. Grippo JF, Holmgren A, Pratt WB. J. Biol. Chem. 1985; 260:93-97. [PubMed: 3965467]

84. Makino Y, Yoshikawa N, Okamoto K, Hirota K, Yodoi J, Makino I, Tanaka H. J. Biol. Chem. 1999; 274:3182-3188. [PubMed: 9915858]

85. Wang H-C, Zentner MD, Deng H-T, Kim K-J, Wu R, Yang P-C, Ann DK. J. Biol. Chem. 2000; 275:8600-8609. [PubMed: 10722699] 
86. Sohn K-C, Jang S, Choi D-K, Lee Y-S, Yoon T-J, Jeon EK, Kim KH, Seo Y-J, Lee J-H, Park J-K, Kim CD. Biochem. Biophys. Res. Commun. 2007; 356:810-815. [PubMed: 17382897]

87. Okamoto K, Tanaka H, Ogawa H, Makino Y, Eguchi H, Hayashi S.-i. Yoshikawa N, Poellinger L, Umesono K, Makino I. J. Biol. Chem. 1999; 274:10363-10371. [PubMed: 10187825]

88. McCarthy MM. Physiol. Rev. 2008; 88:91-134. [PubMed: 18195084]

89. Weitzmann MN, Pacifici R. J. Clin. Invest. 2006; 116:1186-1194. [PubMed: 16670759]

90. Emmen JMA, Korach KS. Gynecol. Endocrinol. 2003; 17:169-176. [PubMed: 12737678]

91. Matthews J, Gustafsson J-Å. Mol. Interventions. 2003; 3:281-292.

92. Björnström L, Sjöberg M. Mol. Endocrinol. 2005; 19:833-842. [PubMed: 15695368]

93. Yue W, Yager JD, Wang J-P, Jupe ER, Santen RJ. Steroids. 2013; 78:161-170. [PubMed: 23178278]

94. Cavalieri E, Chakravarti D, Guttenplan J, Hart E, Ingle J, Jankowiak R, Muti P, Rogan E, Russo J, Santen R, Sutter T. Biochim. Biophys. Acta. 2006; 1766:63-78. [PubMed: 16675129]

95. Liehr JG, Roy D. Free Radic. Biol. Med. 1990; 8:415-423. [PubMed: 2199344]

96. Preston-Martin S, Pike MC, Ross RK, Jones PA, Henderson BE. Cancer Res. 1990; 50:7415-7421. [PubMed: 2174724]

97. Neff S, Sadowski C, Miksicek RJ. Mol. Endocrinol. 1994; 8:1215-1223. [PubMed: 7838154]

98. Reese JC, Katzenellenbogen BS. J. Biol. Chem. 1991; 266:10880-10887. [PubMed: 2040605]

99. Reese JC, Wooge CH, Katzenellenbogen BS. Mol. Endocrinol. 1992; 6:2160-2166. [PubMed: 1491695]

100. Jensen EV, Hurst DJ, DeSombre ER, Jungblut PW. Science. 1967; 158:385-387. [PubMed: 6061892]

101. Katzenellenbogen BS, Bhardwaj B, Fang H, Ince BA, Pakde F, Reese JC, Schodin D, Wrenn CK. J. Steroid Biochem. Mol. Biol. 1993; 47:39-48. [PubMed: 8274440]

102. Lopez S, Miyashita Y, Simons SS. J. Biol. Chem. 1990; 265:16039-16042. [PubMed: 2168876]

103. Maynard AT, Covell DG. J. Am. Chem. Soc. 2001; 123:1047-1058. [PubMed: 11456658]

104. Liang X, Lu B, Scott GK, Chang C-H, Baldwin MA, Benz CC. Mol. Cell. Endocrinol. 1998; 146:151-161. [PubMed: 10022773]

105. Whittal RM, Benz CC, Scott G, Semyonov J, Burlingame AL, Baldwin MA. Biochemistry. 2000; 39:8406-8417. [PubMed: 10913246]

106. Atsriku C, Scott G, Benz C, Baldwin M. J. Am. Soc. Mass Spectrom. 2005; 16:2017-2026. [PubMed: 16246571]

107. Wang LH, Yang XY, Zhang X, Mihalic K, Fan Y-X, Xiao W, Howard OMZ, Appella E, Maynard AT, Farrar WL. Nat. Med. 2004; 10:40-47. [PubMed: 14702633]

108. Garbán HJ, Márquez-Garbán DC, Pietras RJ, Ignarro LJ. Proc. Natl. Acad. Sci. U. S. A. 2005; 102:2632-2636. [PubMed: 15699347]

109. Cronauer MV, Ince Y, Engers R, Rinnab L, Weidemann W, Suschek CV, Burchardt M, Kleinert H, Wiedenmann J, Sies H, Ackermann R, Kröncke K-D. Oncogene. 2006; 26:1875-1884. [PubMed: 16983333]

110. Kröncke K-D, Carlberg C. FASEB J. 2000; 14:166-173. [PubMed: 10627291]

111. Mendelsohn ME, Karas RH. N. Engl. J. Med. 1999; 340:1801-1811. [PubMed: 10362825]

112. Hayashi, S.-i.; Hajiro-Nakanishi, K.; Makino, Y.; Eguchi, H.; Yodoi, J.; Tanaka, H. Nucleic Acids Res. 1997; 25:4035-4040. [PubMed: 9321654]

113. Rao AK, Ziegler YS, McLeod IX, Yates JR, Nardulli AM. J. Mol. Endocrinol. 2009; 43:251-261. [PubMed: 19620238]

114. Damdimopoulos AE, Miranda-Vizuete A, Treuter E, Gustafsson J-Å, Spyrou G. J. Biol. Chem. 2004; 279:38721-38729. [PubMed: 15199063]

115. Schultz-Norton JR, McDonald WH, Yates JR, Nardulli AM. Mol. Endocrinol. 2006; 20:19821995. [PubMed: 16690750]

116. Wilkinson B, Gilbert HF. Biochim. Biophys. Acta. 2004; 1699:35-44. [PubMed: 15158710]

117. Rao AK, Ziegler YS, McLeod IX, Yates JR, Nardulli AM. Mol. Endocrinol. 2008; 22:11131124. [PubMed: 18258688] 
118. Curtis CD, Thorngren DL, Ziegler YS, Sarkeshik A, Yates JR, Nardulli AM. Mol. Endocrinol. 2009; 23:1346-1359. [PubMed: 19460860]

119. Evans AR, Limp-Foster M, Kelley MR. Mutat. Res./DNA Repair. 2000; 461:83-108.

120. Yang S, Meyskens FL. Antioxid. Redox Signal. 2009; 11

121. Tamir S, Izrael S, Vaya J. J. Steroid Biochem. Mol. Biol. 2002; 81:327-332. [PubMed: 12361722]

122. Chakrabarti S, Davidge ST. J. Steroid Biochem. Mol. Biol. 2009; 117:99-106. [PubMed: 19635557]

123. Shao D, Lazar MA. J. Clin. Invest. 1999; 103:1617-1618. [PubMed: 10377165]

124. Weitsman G, Weebadda W, Ung K, Murphy L. Breast Cancer Res. Treat. 2009; 118:269-279. [PubMed: 18941890]

125. Lannigan DA. Steroids. 2003; 68:1-9. [PubMed: 12475718]

126. Zhao Q, Khorasanizadeh S, Miyoshi Y, Lazar MA, Rastinejad F. Mol. Cell. 1998; 1:849-861. [PubMed: 9660968]

127. Sierk ML, Zhao Q, Rastinejad F. Biochemistry. 2001; 40:12833-12843. [PubMed: 11669620]

128. Harding HP, Lazar MA. Mol. Cell. Biol. 1995; 15:4791-4802. [PubMed: 7651396]

129. Zamir I, Zhang J, Lazar MA. Genes Dev. 1997; 11:835-846. [PubMed: 9106656]

130. Horlein AJ, Naar AM, Heinzel T, Torchia J, Gloss B, Kurokawa R, Ryan A, Kamei Y, Soderstrom M, Glass CK, Rosenfeld MG. Nature. 1995; 377:397-404. [PubMed: 7566114]

131. Duez H, Staels B. FEBS Lett. 2008; 582:19-25. [PubMed: 17765229]

132. Ko CH, Takahashi JS. Hum. Mol. Genet. 2006; 15:R271-R277. [PubMed: 16987893]

133. Preitner N, Damiola F, Luis Lopez M, Zakany J, Duboule D, Albrecht U, Schibler U. Cell. 2002; 110:251-260. [PubMed: 12150932]

134. Coste H, Rodríguez JC. J. Biol. Chem. 2002; 277:27120-27129. [PubMed: 12021280]

135. Raspé E, Duez H, Mansén A, Fontaine C, Fiévet C, Fruchart J-C, Vennström B, Staels B. J. Lipid Res. 2002; 43:2172-2179. [PubMed: 12454280]

136. Wang J, Yin L, Lazar MA. J. Biol. Chem. 2006; 281:33842-33848. [PubMed: 16968709]

137. Chandra V, Mahajan S, Saini A, Dkhar HK, Nanduri R, Raj EB, Kumar A, Gupta P. J. Biol. Chem. 2013; 288:10692-10702. [PubMed: 23449984]

138. Gibbs JE, Blaikley J, Beesley S, Matthews L, Simpson KD, Boyce SH, Farrow SN, Else KJ, Singh D, Ray DW, Loudon ASI. Proc. Natl. Acad. Sci. U. S. A. 2012; 109:582-587. [PubMed: 22184247]

139. Yin L, Wu N, Curtin JC, Qatanani M, Szwergold NR, Reid RA, Waitt GM, Parks DJ, Pearce KH, Wisely GB, Lazar MA. Science. 2007; 318:1786-1789. [PubMed: 18006707]

140. Cho H, Zhao X, Hatori M, Yu RT, Barish GD, Lam MT, Chong L-W, DiTacchio L, Atkins AR, Glass CK, Liddle C, Auwerx J, Downes M, Panda S, Evans RM. Nature. 2012; 485:123-127. [PubMed: 22460952]

141. Bugge A, Feng D, Everett LJ, Briggs ER, Mullican SE, Wang F, Jager J, Lazar MA. Genes Dev. 2012; 26:657-667. [PubMed: 22474260]

142. Raghuram S, Stayrook KR, Huang P, Rogers PM, Nosie AK, McClure DB, Burris LL, Khorasanizadeh S, Burris TP, Rastinejad F. Nat. Struct. Mol. Biol. 2007; 14:1207-1213. [PubMed: 18037887]

143. Kaasik K, Chi Lee C. Nature. 2004; 430:467-471. [PubMed: 15269772]

144. Wu N, Yin L, Hanniman EA, Joshi S, Lazar MA. Genes Dev. 2009; 23:2201-2209. [PubMed: 19710360]

145. Phelan CA, Gampe RT, Lambert MH, Parks DJ, Montana V, Bynum J, Broderick TM, Hu X, Williams SP, Nolte RT, Lazar MA. Nat. Struct. Mol. Biol. 2010; 17:808-814. [PubMed: 20581824]

146. Marvin KA, Reinking JL, Lee AJ, Pardee K, Krause HM, Burstyn JN. Biochemistry. 2009; 48:7056-7071. [PubMed: 19405475]

147. Gupta N, Ragsdale SW. J. Biol. Chem. 2011; 286:4392-4403. [PubMed: 21123168] 
148. Pardee KI, Xu X, Reinking J, Schuetz A, Dong A, Liu S, Zhang R, Tiefenbach J, Lajoie G, Plotnikov AN, Botchkarev A, Krause HM, Edwards A. PLoS Biol. 2009; 7:e1000043.

149. Perera R, Sono M, Sigman JA, Pfister TD, Lu Y, Dawson JH. Proc. Natl. Acad. Sci. U. S. A. 2003; 100:3641-3646. [PubMed: 12655049]

150. Reinking J, Lam MMS, Pardee K, Sampson HM, Liu S, Yang P, Williams S, White W, Lajoie G, Edwards A, Krause HM. Cell. 2005; 122:195-207. [PubMed: 16051145]

151. Artinian LR, Ding JM, Gillette MU. Exp. Neurol. 2001; 171:293-300. [PubMed: 11573981]

152. Dioum EM, Rutter J, Tuckerman JR, Gonzalez G, Gilles-Gonzalez M-A, McKnight SL. Science. 2002; 298:2385-2387. [PubMed: 12446832]

153. Zhang L, Guarente L. EMBO J. 1995; 14:313-320. [PubMed: 7835342]

154. Wang TA, Yu YV, Govindaiah G, Ye X, Artinian L, Coleman TP, Sweedler JV, Cox CL, Gillette MU. Science. 2012; 337:839-842. [PubMed: 22859819]

155. Rutter J, Reick M, Wu LC, McKnight SL. Science. 2001; 293:510-514. [PubMed: 11441146]

156. Mainwaring WIP. J. Endocrinol. 1969; 45:531-541. [PubMed: 5366114]

157. Liao M, Zhou Z.-x. Wilson EM. Biochemistry. 1999; 38:9718-9727. [PubMed: 10423251]

158. Park S-Y, Kim Y-J, Gao AC, Mohler JL, Onate SA, Hidalgo AA, Ip C, Park E-M, Yoon SY, Park Y-M. Cancer Res. 2006; 66:5121-5129. [PubMed: 16707435]

159. Herman TS, Fimognari GM, Edelman IS. J. Biol. Chem. 1968; 243:3849-3856. [PubMed: 5661711]

160. Lupo B, Mesnier D, Auzou G. Biochemistry. 1998; 37:12153-12159. [PubMed: 9724527]

161. Souque A, Fagart J, Couette B, Rafestin-Oblin M-E. J. Steroid Biochem. Mol. Biol. 1996; 57:315-321. [PubMed: 8639467]

162. Galigniana MD, Piwien-Pilipuk G. Biochem. J. 1999; 341:585-592. [PubMed: 10417321]

163. Galigniana MD. Life Sci. 1996; 59:511-521. [PubMed: 8761339]

164. Piwien-Pilipuk G, Galigniana MD. Biochim. Biophys. Acta. 2000; 1495:263-280. [PubMed: 10699465]

165. Piwien-Pilipuk G, Ayala A, Machado A, Galigniana MD. J. Biol. Chem. 2002; 277:11896-11903. [PubMed: 11809749]

166. Nagase M, Ayuzawa N, Kawarazaki W, Ishizawa K, Ueda K, Yoshida S, Fujita T. Hypertension. 2012; 59:500-506. [PubMed: 22232135]

167. Ruhs S, Strätz N, Schlör K, Meinel S, Mildenberger S, Rabe S, Gekle M, Grossmann C. Free Radic. Biol. Med. 2012; 53:1088-1100. [PubMed: 22749806]

168. Coty WA, Klooster TA, Griest RE, Profita JA. Arch. Biochem. Biophys. 1983; 225:748-757. [PubMed: 6625609]

169. MacDonald RG, Leavitt WW. J. Biol. Chem. 1982; 257:311-315. [PubMed: 7053373]

170. Peleg S, Schrader WT, O'Malley BW. Biochemistry. 1988; 27:358-367. [PubMed: 3349038]

171. Moudgil VK, Anter MJ, Hurd C. J. Biol. Chem. 1989; 264:2203-2211. [PubMed: 2914901]

172. Coty WA. J. Biol. Chem. 1980; 255:8035-8037. [PubMed: 6251040]

173. Sherman MR, Corvol PL, O'Malley BW. J. Biol. Chem. 1970; 245:6085-6096. [PubMed: 5484467]

174. Peleg S, Schrader WT, O'Malley BW. Biochemistry. 1989; 28:7373-7379. [PubMed: 2819076]

175. Casadevall M, Sarkar B. J. Inorg. Biochem. 1998; 71:147-152. [PubMed: 9833319]

176. Demary K, Wong L, Liou JS, Faller DV, Spanjaard RA. Endocrinology. 2001; 142:2600-2605. [PubMed: 11356710]

177. Park U-H, Han H-S, Um E, An X-H, Kim E-J, Um S-J. Biochem. Biophys. Res. Commun. 2009; 390:241-246. [PubMed: 19799861]

178. Hashimoto S, Imaoka S. J. Biol. Chem. 2013; 288:1706-1716. [PubMed: 23148211]

179. Wecksler WR, Ross FP, Norman AW. J. Biol. Chem. 1979; 254:9488-9491. [PubMed: 489547]

180. Nakajima S, Hsieh J-C, Jurutka PW, Galligan MA, Haussler CA, Whitfield GK, Haussler MR. J. Biol. Chem. 1996; 271:5143-5149. [PubMed: 8617794] 
181. Kröncke K-D, Klotz L-O, Suschek CV, Sies H. J. Biol. Chem. 2002; 277:13294-13301. [PubMed: 11796720]

182. Pryor WA, Squadrito GL. Am. J. Physiol. 1995; 268:L699-L722. [PubMed: 7762673]

183. Cooper CE, Patel RP, Brookes PS, Darley-Usmar VM. Trends Biochem. Sci. 2002; 27:489-492. [PubMed: 12368076] 


\section{Highlights}

- Nuclear receptors are transcription factors involved in diverse cellular processes

- Nuclear receptors contain redox-active thiols that are prone to oxidation

- Thiol oxidation negatively regulates ligand and DNA binding, and nuclear import 

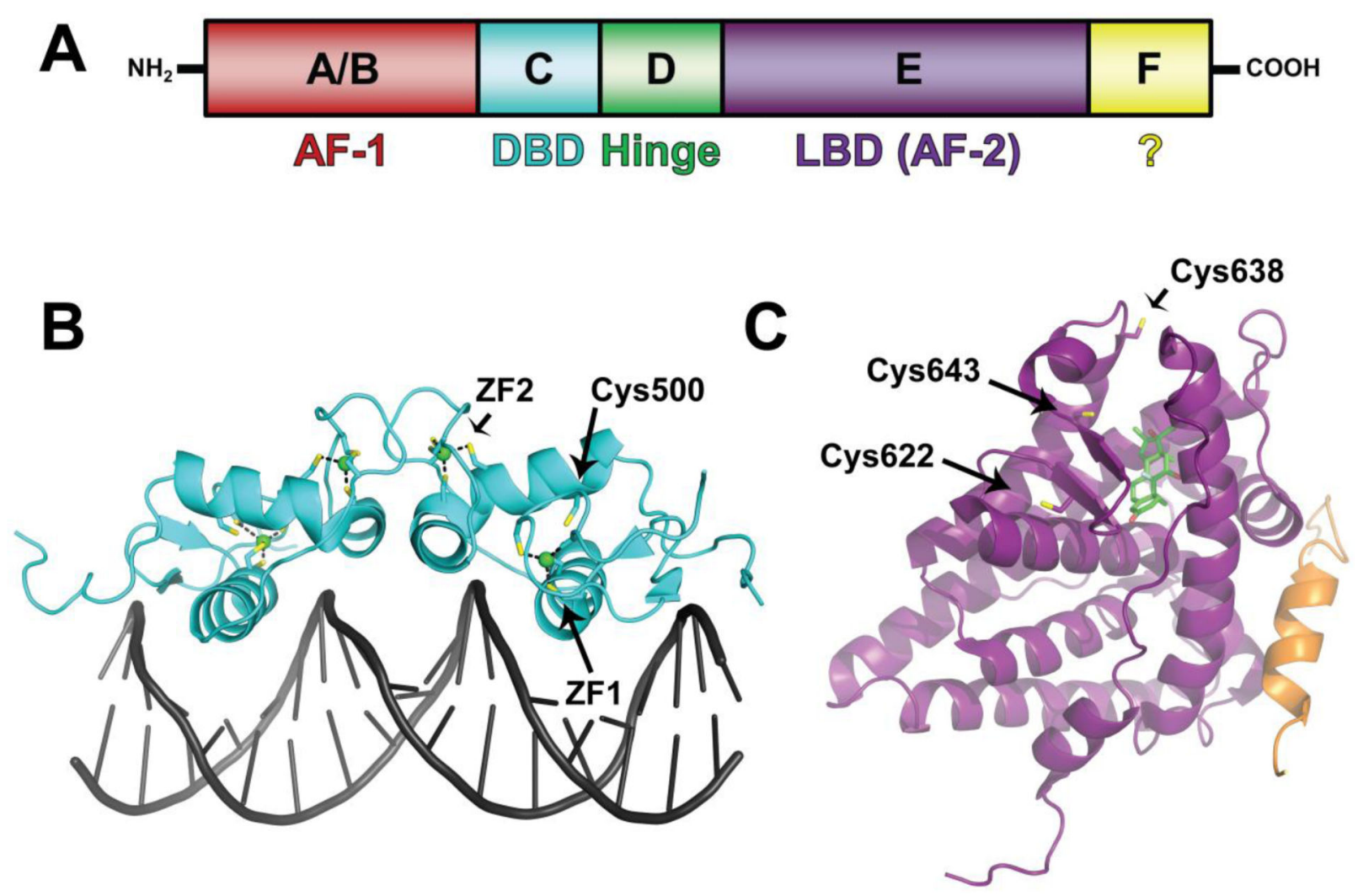

Fig. 1. Nuclear receptor domain organization and three-dimensional structure using glucocorticoid receptor as an example

(A) Modular domain organization of a typical NR. The N-terminal A/B region harbors AF-1 ligand-independent regulatory activity and is a site of phosphorylation. $\mathrm{A} / \mathrm{B}$ is followed by the highly conserved $\mathrm{C}$ region, or DBD that is connected to the LBD (E region, containing ligand-dependent AF-2 activity) by the hinge (D region). Some receptors contain a F region with unknown function. (B) Three-dimensional structure of the rat GR DBD homodimer in complex with a palindromic GRE where the two half-sites are separated by four base pairs (PDB access code 1GLU). Cysteine sulfhydryls involved in redox modulation are highlighted in yellow. In each subunit of the dimer, eight out of nine redox-active cysteine sulfhydryls comprise the two $\mathrm{Cys}_{4}$ zinc-finger motifs (ZF1 and ZF2). The last sulfhydryl of Cys500 (equivalent to Cys481 in the human GR sequence) resides in NLS1 and is conserved among nuclear receptors. (C) Three-dimensional structure of the human GR LBD in complex with the agonist dexamethasone (depicted as sticks with carbon atoms in green, oxygen in red, and fluorine in cyan) and a peptide derived from the coactivator TIF2 (orange) harboring a LXXLL motif (PDB access code 1M2Z). The three cysteine sulfhydryls implicated in redox modulation of ligand binding are highlighted in yellow and labeled; Cys638 and Cys643 are the pair of arsenite-reactive proximal thiols. 
A

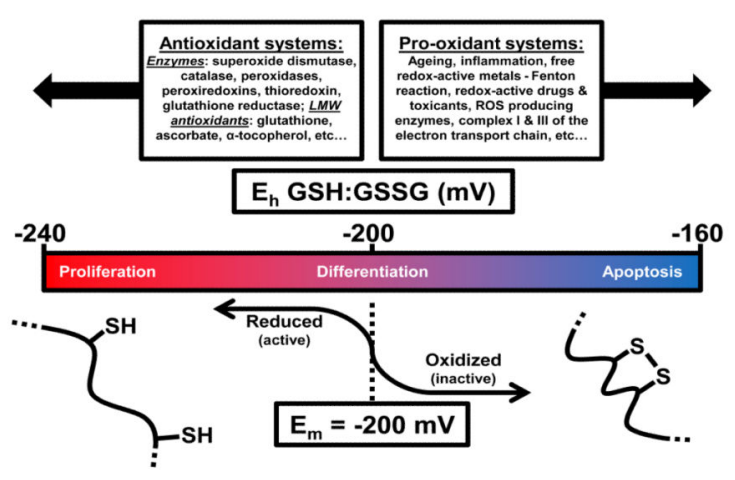

B

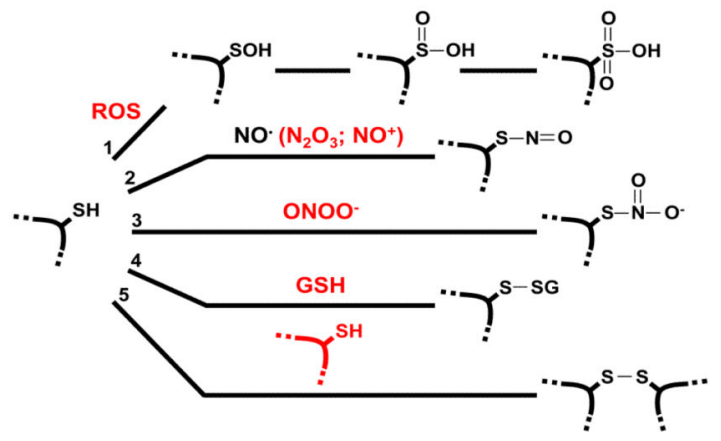

Fig. 2. Cellular redox systems interface with protein thiols

(A) Redox homeostasis is maintained as a balance between opposing antioxidant and prooxidant systems. However, homeostasis is a relative term considering the ambient potential of glutathione, the major cellular redox buffer, can vary dramatically depending on the growth stage of a cell. Proteins containing redox active thiol-disulfide couples will respond to the ambient potential in a Nernstian fashion as long as the $\mathrm{E}_{\mathrm{m}}$ (midpoint potential) of the couple falls within the physiologically relevant range. To illustrate this point a hypothetical thiol-disulfide that controls the activity of a protein is depicted; the $\mathrm{E}_{\mathrm{m}}$ of the couple is -200 $\mathrm{mV}$ and the dithiol form of the protein is active while the disulfide is inactive. When the cell is proliferating and the ambient potential is highly reducing the couple exists as a dithiol.

Conversely, a cell undergoing apoptosis can be $+80 \mathrm{mV}$ oxidized favoring an intramolecular disulfide that alters quaternary structure and inactivates the protein. Adapted from [9]. (B) Many other thiol oxidation products exist besides intramolecular disulfides. For simplicity a single reduced protein thiol is depicted with oxidizing species in red: 1) ROS can successively oxidize thiols to sulfenic (-SOH), sulfinic $\left(-\mathrm{SO}_{2} \mathrm{H}\right)$, and sulfonic $\left(-\mathrm{SO}_{3} \mathrm{H}\right)$ acids; 2) Autooxidation products of nitric oxide, such as dinitrogen trioxide, or species with $\mathrm{NO}^{+}$ character react with thiols to form thionitrites ( $S$-nitrosothiols); 3) Peroxynitrite reacts with thiols generating a thionitrate that may be an intermediate in the formation of disulfides, a major peroxynitrite-driven thiol oxidation product [182]; 4) Low molecular weight thiols like GSH can form disulfides with protein thiols under oxidizing conditions; 5) Similarly, thiols of different proteins can form intermolecular disulfides. Adapted from [183]. 

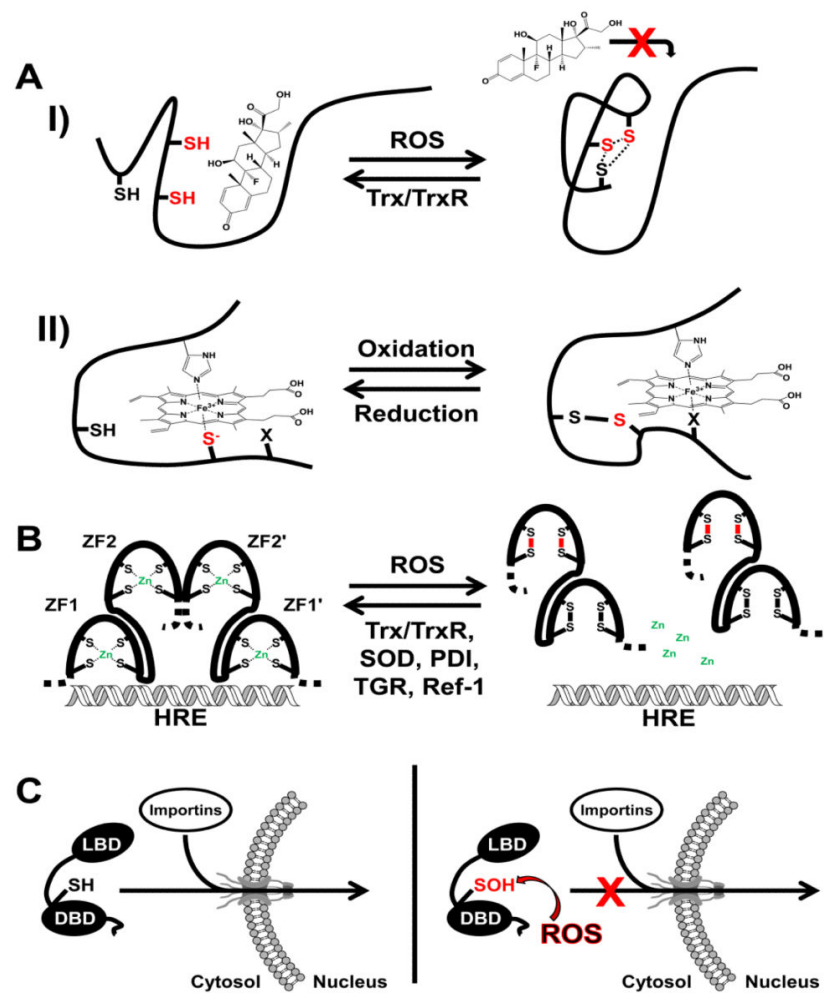

Fig. 3. Key modes of redox modulation of nuclear receptor function

(A) Two examples are depicted in which the redox status of sulfhydryls in the ligandbinding domain govern the ability of the receptor to effectively associate with ligand. I) In the thiol-reduced state the glucocorticoid receptor binds the agonist, dexamethasone that ultimately leads to nuclear import and the regulation of target gene transcription. Under conditions of oxidative stress ROS cause the formation of disulfide bonds between any of three cysteine sulfhydryls in close proximity to the ligand-binding pocket. Inspection of the GR LBD crystal structure suggests that in order for these disulfides to form a large conformational change would have to take place that could occlude access to dexamethasone or other glucocorticoids. The dashed lines represent potential disulfides and the two red sulfhydryls comprise the arsenite-reactive proximal thiols unique to GR. In the reverse direction, Trx and TrxR have been implicated in the reduction of thiol oxidized GR and the recovery of steroid-binding capacity. II) Under reducing conditions the Rev-erb $\beta$ LBD binds ferric heme with high affinity as a 6-coordinate complex with histidine and cysteine thiolate (depicted in red, Cys384) axial ligands. An oxidizing environment leads to the sequestration of the axial cysteine thiolate as a disulfide with Cys374 and the concomitant replacement of Cys384 as a heme ligand by an unidentified neutral residue, $\mathrm{X}$. The thiol-oxidized protein has a $\sim 5$-fold decreased affinity for heme which could have a significant impact on the ability of Rev-erb $\beta$ to recruit NCoR and repress target gene transcription. (B) NR DBD zinc-fingers are targets of ROS damage. Under reducing conditions zinc-fingers are maintained as a tetrahedral complex between cysteine thiolates and $\mathrm{Zn}^{2+}$ that impart structural stability important for binding DNA and dimerization. ROS lead to the formation of disulfides between zinc-finger sulfhydryls with subsequent ejection of $\mathrm{Zn}^{2+}$ and structural destabilization that ultimately causes dimer dissociation and a loss of 
DNA binding capacity. As demonstrated for ER, ZF2 is highly susceptible to thiol oxidation thus disulfide bonds in ZF2 are shown in red. The reduction and recovery of oxidized ER DBD disulfides are facilitated by an interaction with redox mediators in the nucleus including Trx/TrxR, SOD, PDI, and Ref-1. Trx has also been implicated in the repair of thiol oxidized GR DBD, the hybrid thiol-disulfide oxidoreductase TGR similarly affects RAR, and Ref-1 modulates TR activity suggesting a general mechanism in which thiol-disulfide oxidoreductases, chaperones, and antioxidant enzymes maintain the reduced and active forms of NRs in the cell. HRE: Hormone Response Element. (C) Nuclear translocation of GR is subject to redox modulation through the oxidation of Cys500 (rat amino acid numbering, equivalent to Cys481 in human GR), a conserved cysteine sulfhydryl that resides in NLS1 C-terminal to ZF2 (depicted as a -SH group). Under reducing conditions importin proteins interact with NLS1 leading to the translocation of GR to the nucleus through a nuclear pore. On the other hand, ROS that arise during oxidative stress can oxidize Cys500 and impede nuclear translocation. A sulfenic acid intermediate is depicted as it is unclear what the Cys500 oxidation product is, but could certainly include an intra- or intermolecular disulfide, or higher sulfur oxide that may inhibit the ability of GR to interact with importin proteins. 

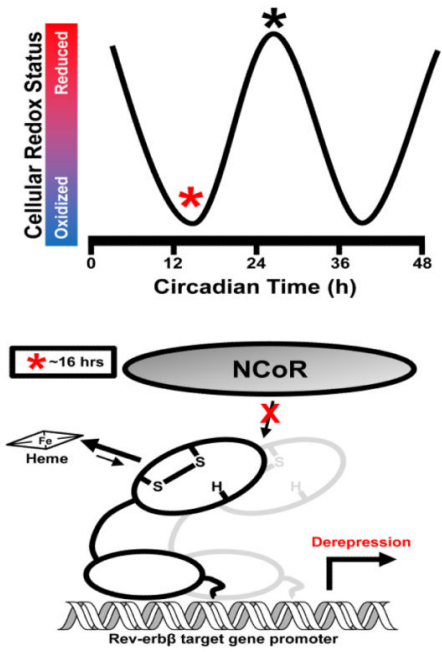

* -28 hrs

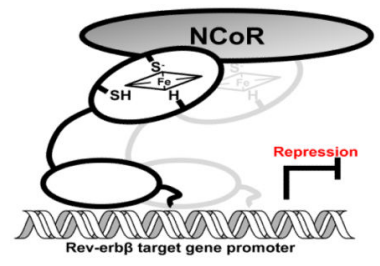

Fig. 4. A working hypothesis for the role of the Rev-erb $\beta$ thiol-disulfide switch in syncing repressor function with rhythmic changes in suprachiasmatic nucleus cellular redox status Several redox systems display rhythmic cycles of reduction/oxidation in rodent SCN tissue including FAD/NADPH cofactors, protein glutathionylation, and ascorbate [154]. In terms of rodent circadian time, SCN tissue redox status (measured by the ratio of FAD:NADPH) is maximally oxidized at $\sim 16 \mathrm{~h}$ (early night); these conditions would seemingly favor the disulfide form of the Rev-erb $\beta$ thiol-disulfide switch, lowering the affinity of the receptor for heme and impeding the ligand-dependent recruitment of NCoR ultimately leading to the derepression of target gene transcription. Conversely, at 28 hours clock time (daytime) $\mathrm{SCN}$ tissue is maximally reduced and would favor the dithiol form of the switch which has a high affinity for heme with His $(\mathrm{H})$ and Cys axial ligands. In the heme bound state Rev-erb $\beta$ recruits NCoR leading to gene repression. 